\title{
Report on FY 2020 Welding Parameters Optimization and the Fabrication of Qualified Alloy 709 Welds
}

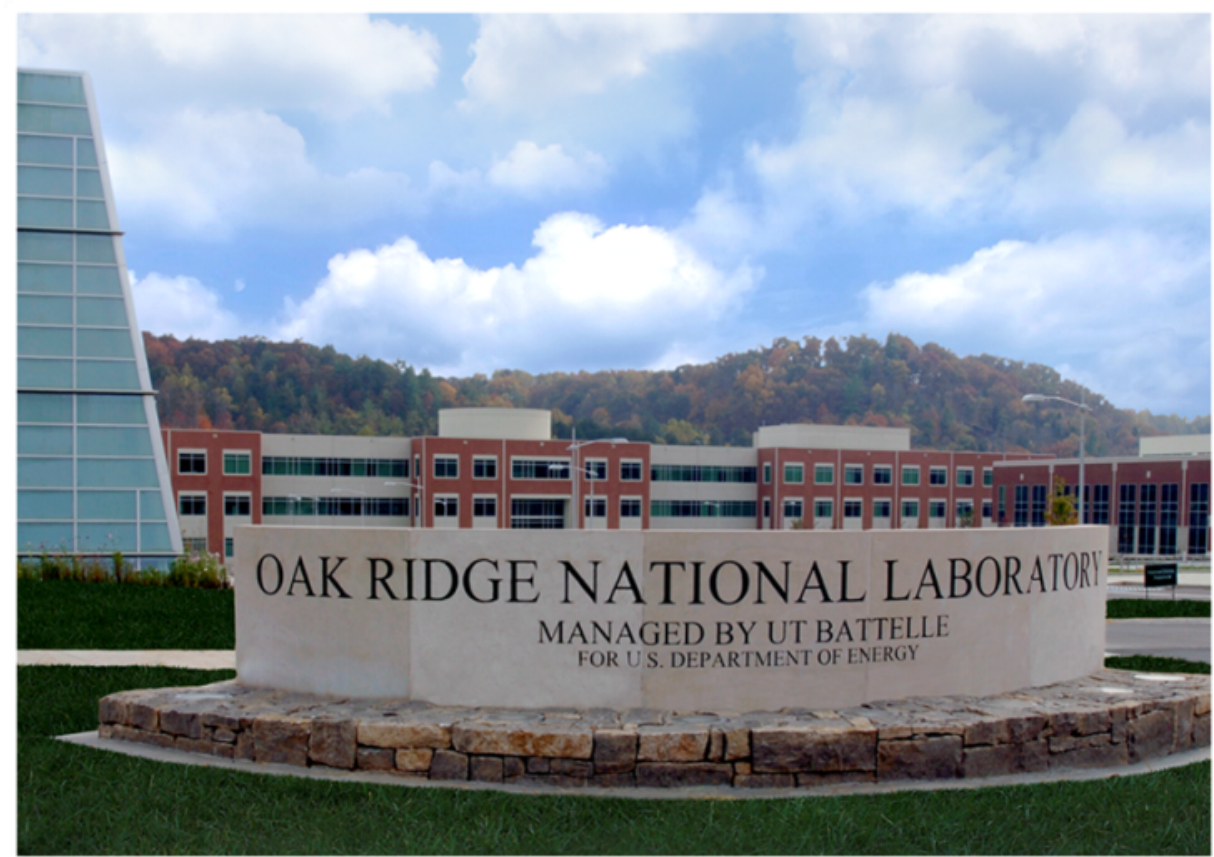

Zhili Feng

Tao Dai

Doug Kyle

Yiyu Wang

Yanli Wang

September 2020

Approved for public release.

Distribution is unlimited. 


\title{
DOCUMENT AVAILABILITY
}

Reports produced after January 1, 1996, are generally available free via US Department of Energy (DOE) SciTech Connect.

\section{Website http://www.osti.gov/scitech/}

Reports produced before January 1, 1996, may be purchased by members of the public from the following source:

\author{
National Technical Information Service \\ 5285 Port Royal Road \\ Springfield, VA 22161 \\ Telephone 703-605-6000 (1-800-553-6847) \\ TDD 703-487-4639 \\ Fax 703-605-6900 \\ E-mailinfo@ntis.gov \\ Website http://www.ntis.gov/help/ordermethods.aspx
}

Reports are available to DOE employees, DOE contractors, Energy Technology Data Exchange representatives, and International Nuclear Information System representatives from the following source:

Office of Scientific and Technical Information

PO Box 62

Oak Ridge, TN 37831

Telephone 865-576-8401

Fax 865-576-5728

E-mail reports@osti.gov

Website http://www.osti.gov/contact.html

This report was prepared as an account of work sponsored by an agency of the United States Government. Neither the United States Government nor any agency thereof, nor any of their employees, makes any warranty, express or implied, or assumes any legal liability or responsibility for the accuracy, completeness, or usefulness of any information, apparatus, product, or process disclosed, or represents that its use would not infringe privately owned rights. Reference herein to any specific commercial product, process, or service by trade name, trademark, manufacturer, or otherwise, does not necessarily constitute or imply its endorsement, recommendation, or favoring by the United States Government or any agency thereof. The views and opinions of authors expressed herein do not necessarily state or reflect those of the United States Government or any agency thereof. 
Materials Science and Technology Division

\title{
REPORT ON FY 2020 WELDING PARAMETERS OPTIMIZATION AND THE FABRICATION OF QUALIFIED ALLOY 709 WELDS
}

\author{
Zhili Feng \\ Tao Dai \\ Doug Kyle \\ Yiyu Wang \\ Yanli Wang
}

September 2020

Prepared by

OAK RIDGE NATIONAL LABORATORY

Oak Ridge, TN 37831-6283

managed by

UT-BATTELLE, LLC

for the

US DEPARTMENT OF ENERGY

under contract DE-AC05-00OR22725 



\section{CONTENTS}

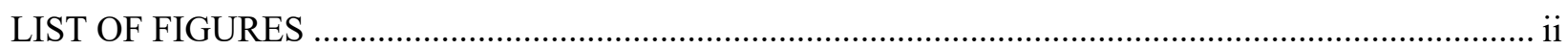

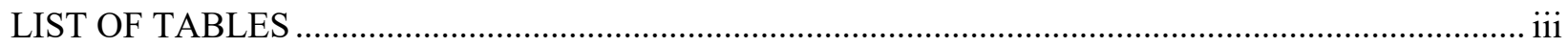

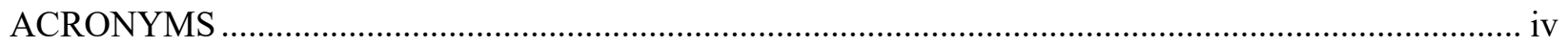

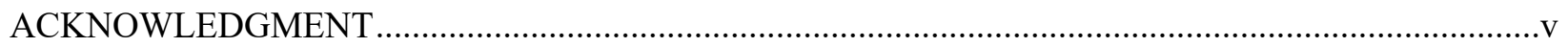

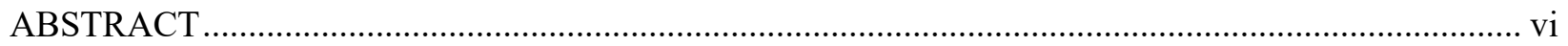

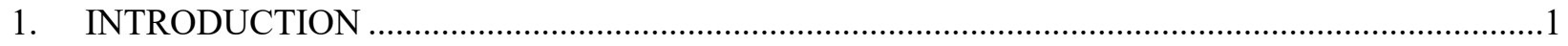

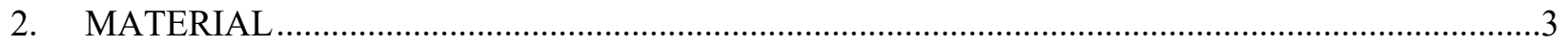

3. WELDING OF ALLOY 709 AND QUALIFICATION TESTING …............................................

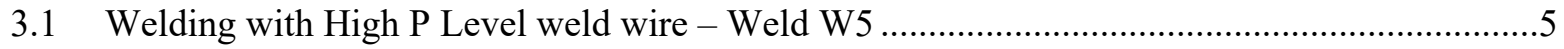

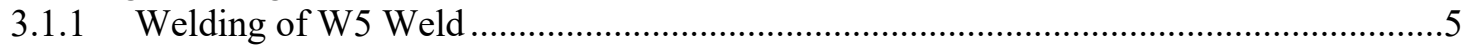

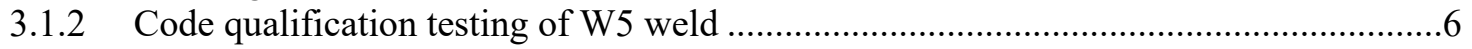

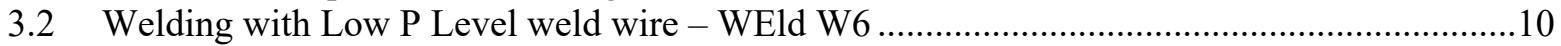

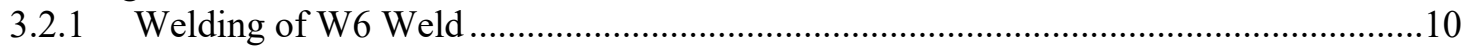

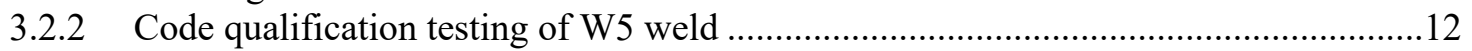

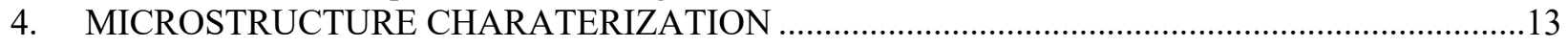

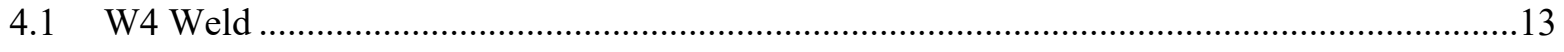

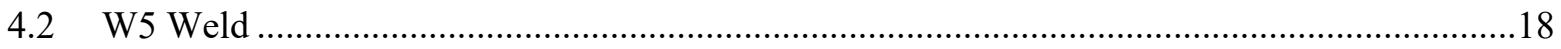

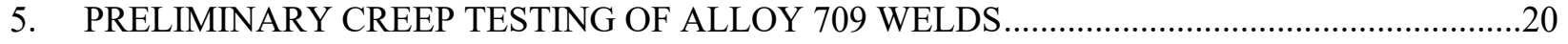

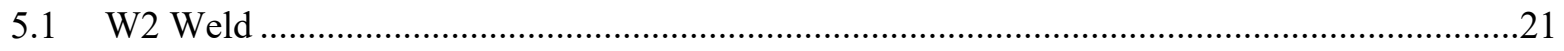

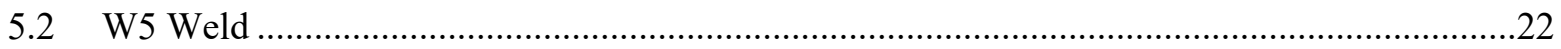

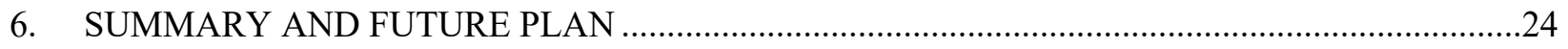

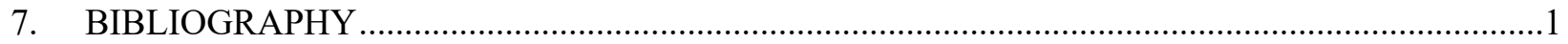




\section{LIST OF FIGURES}

Figure 1. Single V-groove joint preparation details used in the study ..................................................4

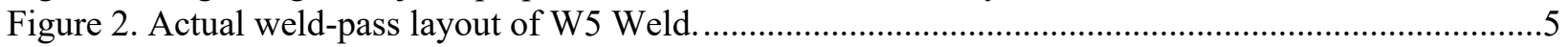

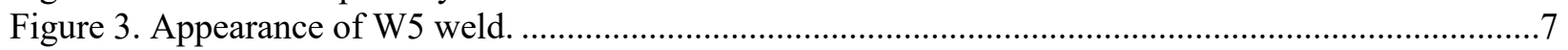

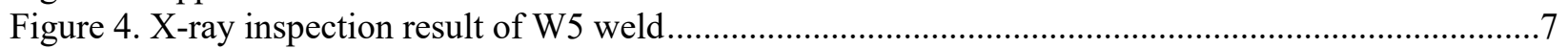

Figure 5. Layout of the test specimens from Weld W5 . ..................................................................

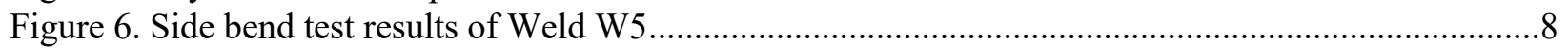

Figure 7. Room temperature cross-weld tensile results for 709 weld W5 .........................................

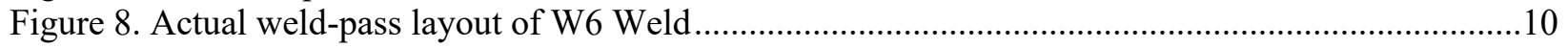

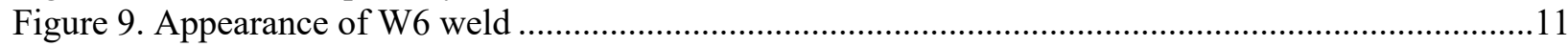

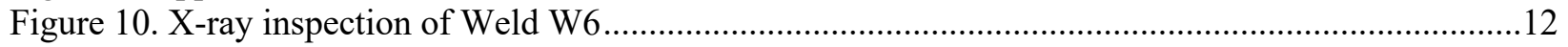

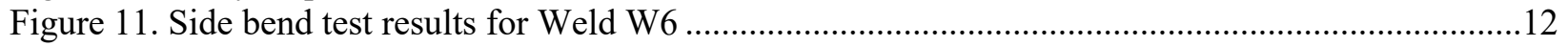

Figure 12. Cross-weld view of the W4 weld. Sub-mm weld cracks were found near the top

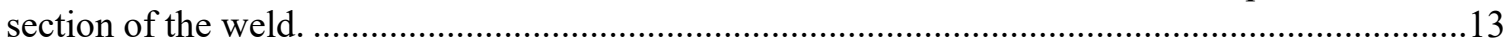

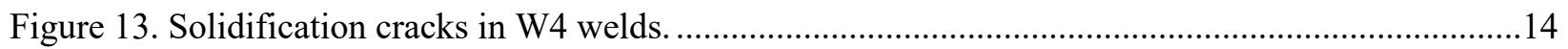

Figure 14. Macro-scale and meso-scale EPMA line scans across the multi-pass weld.............................15

Figure 15. EPMA map scan covering grain boundaries and a crack .....................................................16

Figure 13. EBSD mapping of a region with cracks. ......................................................................... 18

Figure 14. (a) the overview of 709 weld-5, (b) the cracks in region 1 of Fig. $4 a$, (c) the crack in region 2 of Fig. 4a, and (d) the cracks in region 3 of Fig. 4a.....................................................19

Figure 15. Comparison of the creep test results on W2 weld with Alloy 709 base metal ..........................21

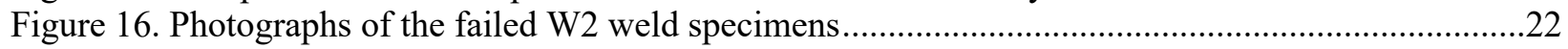

Figure 17. Comparison of the creep test results on W5 weld with Alloy 709 base metal .........................22

Figure 18. Photographs of the failed W5 weld specimens....................................................................23 


\section{LIST OF TABLES}

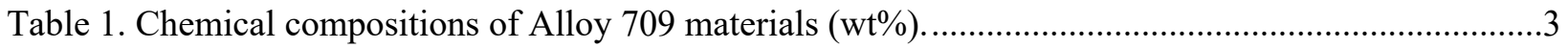

Table 3. Welding parameters for W5 weld (with 140wppm P weld wire) ............................................6

Table 4. Room temperature cross-weld tensile results for 709 weld W5 ................................................

Table 5. Welding parameters for W6 weld (with <20wppm P weld wire) .............................................11

Table 7. Summary of the welds fabricated with V-groove geometry on the $1^{\text {st }}$ commercial heat

Alloy 709 


\section{ACRONYMS}

AOD Argon-Oxygen-Decarburization

ART Advanced Reactor Technologies

ASME

The American Society of Mechanical Engineers

ASTM

DOE

American Society for Testing and Materials. (aka, ASTM International)

ESR

Department of Energy

GTAW

FCC

Electroslag remelting

Gas Tungsten Arc Welding

NDE

Face Centered Cubic

ORNL

SFR

Nondestructive examination

Oak Ridge National Laboratory

SA

Sodium Fast Reactor

Solution Annealed 


\section{ACKNOWLEDGMENT}

This research was sponsored by the US Department of Energy (DOE), Office of Nuclear Energy (NE), under contract No. DE-AC05-00OR22725 with Oak Ridge National Laboratory (ORNL), managed and operated by UT-Battelle, LLC. Programmatic direction was provided by the Office of Nuclear Reactor Deployment of the Office of Nuclear Energy (DOE NE).

The authors gratefully acknowledge the support provided by Brian Robinson, DOE-NE, Federal Manager, Fast Reactors Campaign, Advanced Reactor Technologies (ART) Program, Sue Lesica, Federal Manager, Advanced Materials, ART Program, Robert Hill of Argonne National Laboratory (ANL), National Technical Director, Fast Reactors Campaign, ART Program, and T.-L. Sham of ANL, Technology Area Lead, Advanced Materials, ART Program.

The authors also wish to thank ORNL staff members Jian Chen and Lianshan Lin for reviewing this report. 


\begin{abstract}
Alloy 709 is an attractive candidate construction material for the Sodium Fast Reactor (SFR). As part of the Alloy 709 Intermediate Term Test Program, this work covers the development of the technical basis for weld fabrication and weld qualification of Alloy 709. The phase of research reported herein focused on the issue of weld solidification cracking recently experienced in both experimental heats and a commercial heat of Alloy 709 with relatively high phosphorous levels.
\end{abstract}

This report summarizes the research conducted in FY 2020 and relevant results from previous reporting periods, aimed at welding commercial heat of Alloy 709 plates of relatively high $P$ level (140wppm) in support of ASME code qualification. Welding, code qualification tests, and associated microstructure characterization were carried out in determining the effect of $P$ levels of weld wire on the weldability of the high P commercial heat of Alloy 709.

The study confirmed the detrimental effect of high level of $\mathrm{P}$ on weldability and the mechanical properties of Alloy 709 weld. For the commercial heat of Alloy 709 with relatively high P level (140wppm), it is possible to successfully weld it with a low phosphorous $(20 \mathrm{wppm})$ weld wire using the typical gas tungsten arc welding process and welding input levels. The preliminary weld creep showed little or no creep resistance reduction. On the other hand, micro cracks or fissures are observed when the phosphorous level in the weld wire increases to $140 \mathrm{wppm}$. The study found that optimizing the welding process conditions such as weld wire size and welding heat input improved the weldability, although additional R\&D is necessary to completely eliminate the micro-cracks at $140 \mathrm{wppm}$ level of $\mathrm{P}$ in the weld metal. Initial weld creep test indicated that the micro-cracks that are formed due to $\mathrm{P}$ segregation at solidification grain boundary during welding, although acceptable to ASME Sec IX weld qualification requirement, would potentially cause premature rupture under low-temperature and high-stress creep testing conditions. On the other hand, such micro-cracks appeared to have minimal effect to weld creep test under lower stress and higher temperature conditions.

Computational simulations conducted in previous FY revealed that that phosphorous would segregate to grain boundaries as a result of non-equilibrium solidification process during welding. At high P level, grain boundary segregation would greatly increase the solidification temperature range, leading to increase in the susceptibility of weld solidification cracking of Alloy 709. EPMA micro-chemistry measurement conducted in this reporting period confirmed the computational simulation prediction of grain boundary segregation of $\mathrm{P}$. The micro-chemistry measurement also revealed the meso-scale variations of $\mathrm{P}$ within a weld pass. However, macro-scale $\mathrm{P}$ segregation/accumulation across different weld passes was not apparent based on the micro-chemistry measurement.

This report fulfills the FY2020 milestone M3AT-20OR020502031- "Complete FY19 fabrication and evaluation of weldments for Alloy 709 commercial heat plates" under the ORNL work package AT19OR02050203- “A709 Development-ORNL”. 


\section{INTRODUCTION}

Advanced materials can have a significant impact on flexibility, safety, and economics of the future sodium fast reactor (SFR). This is due to innovative designs and design simplifications that could be made possible using materials with enhanced mechanical properties. Improved materials performance also impacts safety through improved reliability and greater design margins. Improved material reliability could also result in reduced down time.

Alloy 709 is an advanced nitrogen-stabilized and niobium-strengthened austenitic stainless steel. Compared to reference construction material 316H stainless steel for SFR, Alloy 709 has enhanced creep strength, good steam oxidation resistance and hot corrosion resistance. It is an attractive candidate construction material for SFR systems (Busby, et al. 2008). Code qualification of Alloy 709 is underway as part of the Advanced Materials Development program (Sham and Natesan 2017), to provide the technical basis needed to support the regulatory requirements for structural materials required for advanced, non-light water reactors that could be deployed in the near-to-mid-term.

Welding is essential in construction of SFR structures. The code case qualification for SFR would require the development of a sound technical basis for welding of Alloy 709. It would include the development of welding guidelines with supporting testing results to fabricate ASME Section IX (ASME 2019) qualified welds using weld wires with appropriately specified chemistry range, to eliminate stress relaxation cracking issues, and to retain the good cross-weld creep rupture performance, for selected plate heats meeting relevant ASTM/ASME chemistry specifications.

Alloy 709 is derived from NF709, i.e., TP310MoCbN (UNS S31025) specified in ASTM A213-15C (ASTM International 2015). NF709 seamless tube was developed by Nippon Steel Corporation in Japan for boiler tubing applications. Previous studies such as these by Nippon Steel (2013), suggested that NF709 has relatively good weldability. Alloy 709 matching filler metal and Alloy 625 filler metal were the two weld metals that Nippon Steel had recommended to weld seamless tubing. Performance of Alloy 709 weldment fabricated using Alloy 625 filler metal in sodium was found to be less than optimal during the Alloy 709 intermediate term testing program because of the high solubility of nickel in sodium. Weldment fabricated from Alloy 709 matching filler metal was found to have good sodium compatibility. However, more recent welding studies on experimental heats of Alloy 709 in plate form at ORNL (Yamamoto 2014) revealed potential issues of weld solidification cracking when the level of impurities such as $\mathrm{P}$ is high but still within the ASTM A-213-15C specification. So far, only the weldment with very low P content (less than $20 \mathrm{wppm}$, or $0.002 \mathrm{wt} \%$ ) in both the base metal (plate form) and the matching filler metal passed the ASME Section IX weldment qualification test. While a Section IX qualified weldment was fabricated successfully, the requirement of very low P content $(20 \mathrm{wppm})$ places a severe restriction.

The objective of this study was to research and develop suitable welding techniques that would successfully weld Alloy 709 base metal with higher P content within the limit of ASTM A-213-15C specification. To this end, computational solidification simulation modeling was first carried out in 2018 (Feng, et al. 2018) to investigate the solidification behavior of Alloy 709. The roles of alloying elements, in particular the impurity elements $\mathrm{P}, \mathrm{S}$, and B on solidification behavior and susceptibility of weld solidification cracking were systematically analyzed and identified using the computational simulation model. Scheil simulations of non-equilibrium solidification were performed to simulate the solidification during welding. Equilibrium calculations were also made for comparison. It was found that $\mathrm{P}$ has the most important impact on solidification behavior. Increasing levels of P from $0.002 \mathrm{wt} \%(20 \mathrm{wppm})$ to $0.018 \mathrm{wt} \%(180 \mathrm{wppm})$ led to a decrease in the solidus temperature of over $300^{\circ} \mathrm{C}$. That is, high levels of phosphorous lead to very large increases in the non-equilibrium solidification temperature range. Thus, $\mathrm{P}$ is expected to significantly increase the susceptibility of weld solidification cracking of Alloy 709 . This 
conclusion was supported by limited experimental data that showed poor weldability and considerable cracking for experimental Alloy 709 heats (less than 20wppm P) when welded with weld wires of high P levels (Yamamoto, 2014).

The knowledge obtained from the computational modeling above leads to the development of strategies to weld Alloy 709 having wide range of chemistries without weld solidification cracking to support code qualification. One of the approaches was to limit the P level of the weld wire when welding Alloy 709 having relatively high $\mathrm{P}$. For weld wires with high $\mathrm{P}$ levels, special welding procedures or innovative welding techniques may be necessary to produce code qualified welds.

This report summarizes the research progress following the above-mentioned strategy. It was aimed at welding commercial heat of Alloy 709 plates of relatively high P level (140wppm) in support of code qualification. Welding, code qualification tests, and associated microstructure characterization were carried out in determine the effect of $\mathrm{P}$ levels of weld wire on the weldability of this high $\mathrm{P}$ commercial heat of Alloy 709. 


\section{MATERIAL}

The Alloy 709 base metal was the first commercial heat produced within U.S. as part of the DOE/ORNL Alloy 709 scale up production program. This commercial heat was produced by G.O. Carlson Inc. in Pennsylvania (Carlson Heat 58776). This heat of Alloy 709 was processed by either Argon-OxygenDecarburization (AOD) or by electroslag remelting (ESR). They were subsequently hot rolled and solution annealed (SA). The manufacture process of the plates can be found in the report by (Natesan, et al. 2017). The Alloy 709 plates used in this study are ESR plates with two SA temperatures, i.e., SA at $1100^{\circ} \mathrm{C}$ (Heat No 58776-3RBB) and SA at $1150^{\circ} \mathrm{C}$ (Heat No 58776-3RBC). The AOD plates were either solution annealed at $1050^{\circ} \mathrm{C}$ (Heat No $58776-4 \mathrm{~A}$ ) or at $1100^{\circ} \mathrm{C}$ (Heat No 58776-4B). The chemical compositions of the Alloy 709 plates used in this study are listed in Table 1, along with these in the ASTM A213 specification. Note that this commercial "Carlson" heat has relatively high P level at 0.014 $\mathrm{wt} \%$ (140wppm).

The computational simulation of solidification behavior of Alloy 709 (Feng, et al. 2018) suggests that $P$ is a major detrimental factor for weld solidification cracking. An effective solution would be to control the amount of $\mathrm{P}$ in the weld region for defect free weld. To this end, two P levels for the weld wires were selected, based on the availability of material to the study, to investigate the effect of P level in weld wire on the weldability and cracking of the commercial heat Alloy 709. The weld wire with low P content of less than $0.002 \mathrm{wt} \%$ (20wppm) was produced from an experimental heat of Alloy 709 (Heat No. 01136708). The weld wire with higher P level was fabricated from the commercial "Carlson" heat of Alloy 709 AOD plate with SA at $1050^{\circ} \mathrm{C}$ (lot ID 58776-4A1). Thus, this higher P weld wire had the same P level as the AOD plate at $140 \mathrm{wppm}$. The chemical compositions of these two types of weld wires are listed in Table 1. Both weld wires were fabricated by a commercial weld wire drawing process.

Table 1. Chemical compositions of Alloy 709 materials (wt\%).

\begin{tabular}{|c|c|c|c|c|c|c|c|c|c|c|c|c|c|c|c|}
\hline $\begin{array}{c}\text { Heat or } \\
\text { Lot ID }\end{array}$ & $\mathbf{C}$ & $\mathrm{Cr}$ & Co & $\mathbf{N i}$ & Mn & Mo & $\mathbf{N}$ & Si & $\mathbf{P}$ & $\mathbf{S}$ & $\mathbf{T i}$ & Nb & Al & B & $\mathrm{Cu}$ \\
\hline $\begin{array}{c}* 58776- \\
3 \mathrm{RBB} / \\
58776- \\
3 \mathrm{RBC}\end{array}$ & 0.066 & 20.05 & 0.02 & 25.14 & 0.90 & 1.51 & 0.152 & 0.38 & 0.014 & 0.001 & 0.01 & 0.26 & 0.02 & 0.0030 & 0.06 \\
\hline $\begin{array}{c}* * 58776- \\
4 \mathrm{~A} 1 / \mathrm{B} \\
\end{array}$ & 0.07 & 19.93 & 0.02 & 24.98 & 0.91 & 1.51 & 0.148 & 0.44 & 0.014 & $<.000$ & 0.04 & 0.26 & 0.02 & 0.0045 & 0.06 \\
\hline $\begin{array}{c}011367- \\
08 \\
\end{array}$ & 0.079 & 20.03 & $<0.01$ & 25.05 & 0.87 & 1.48 & 0.156 & 0.28 & $<0.002$ & $<0.0003$ & $<0.01$ & 0.28 & 0.02 & 0.003 & $<0.01$ \\
\hline $\begin{array}{c}\text { ASTM } \\
\text { A213 } \\
\text { Spec } \\
\end{array}$ & $<0.10$ & $\begin{array}{l}19.0- \\
23.0\end{array}$ & & $\begin{array}{c}22.0- \\
28.0\end{array}$ & $<1.50$ & $\begin{array}{l}1.0- \\
2.0\end{array}$ & $\begin{array}{c}0.10- \\
0.25\end{array}$ & $<1.00$ & $<0.030$ & $<0.030$ & $<0.20$ & $\begin{array}{c}0.10- \\
0.40\end{array}$ & & $\begin{array}{c}0.002- \\
0.010\end{array}$ & \\
\hline \multicolumn{16}{|l|}{ Note: } \\
\hline $\begin{array}{l}\text { 2) } \\
\text { 3) } \\
\text { 4) }\end{array}$ & $\begin{array}{l}* 58776 \\
* * 58776 \\
+01136\end{array}$ & $\begin{array}{l}\mathrm{RBB} \text { is } \\
\text { 4A1/B i } \\
08\end{array}$ & $\begin{array}{l}\text { lloy } 70 \\
\text { Alloy } 7 \\
\text { sed to f }\end{array}$ & $\begin{array}{l}\text { ESR S } \\
9 \text { AOD } \\
\text { bricate }\end{array}$ & $\begin{array}{r}1100^{\circ} \mathrm{C} \\
\text { A } 1050 \\
\text { he Alloy }\end{array}$ & $\begin{array}{l}\text { and } 5 \\
\mathrm{C} \text {, an } \\
700 \text { lo }\end{array}$ & $\begin{array}{l}776-3 R \\
\text { was us } \\
\text { P wel }\end{array}$ & $\begin{array}{l}\mathrm{C} \text { is All } \\
\text { to fabı } \\
\text { wire. }\end{array}$ & $\begin{array}{l}\text { y } 709 \mathrm{E} \\
\text { cate the }\end{array}$ & $\begin{array}{l}\text { SA } 1150 \\
\text { lloy } 709\end{array}$ & C & wire & & & \\
\hline
\end{tabular}

Recent studies (McMurtrey,) showed that an additional precipitation aging heat treatment of the SA plate notably improved the base metal creep-fatigue life although slightly decreased the creep resistance. In order to achieve optimized high temperature mechanical properties, some of the 58776-3RBC base metal plates used in this study was subjected to an additional heat treatment at $775^{\circ} \mathrm{C}$ for $10 \mathrm{hr}$ (designated as 58776-3RBC-HT). Whilst this additional heat treatment step was effective in producing strengthening precipitates in the base metal, subsequent welding could affect the microstructure in the heat affected zone of the weldment. In this study, welds were made under both as-SA conditions, and with the additional heat treatment step. 


\section{WELDING OF ALLOY 709 AND QUALIFICATION TESTING}

Three different heat-treated Alloy 709 plates from the commercial "Carlson" Alloy 709 heat were used in study. They were AOD Solution Annealed at 1100C (Heat No 58776-4B), ESR Solution Annealed at 1100C (Heat No 58776-3RBB), and ESR Solution Annealed 1150C and heat treated at 750C (Heat No 58776-3RBC-HT). All plates were ground to remove surface cracks and defects before welding. The plate surface was inspected by dye penetrant (Figure $1 \mathrm{~b}$ ) to ensure all the surface defects were effectively removed. For Weld ID W1 (AOD plate), the final plate thickness after machining and grinding was $20 \mathrm{~mm}$ nominal. For all other welds on the ERS plates (Weld ID W2-W6), the final thickness was $28.5 \mathrm{~mm}$ nominal. These plates were butt-welded with single V-groove joint details as shown in Figure 1. Gas tungsten arc welding (GTAW) was used to make these welds. A total of 6 different combinations of base metal and weld wires has been tested so far, which is summarized in Table 2. It is noted that the base metal plates had relatively high $\mathrm{P}$ level at 140wppm, and two weld wires had two different P levels: the low P level at less than 20wppm, and the high P level at 140wppm.

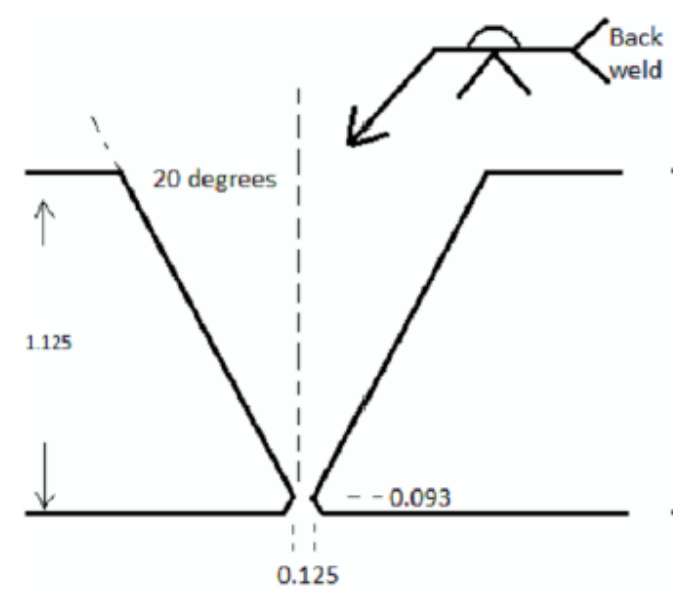

Figure 1. Single V-groove joint preparation details used in the study

Table 2. Combination of weld wire and base metal conditions investigated in this study

\begin{tabular}{|c|c|c|c|c|c|}
\hline \multirow{2}{*}{$\begin{array}{l}\text { Weld } \\
\text { ID }\end{array}$} & \multirow{2}{*}{ Weld Wire } & \multirow{2}{*}{ Base Metal } & \multicolumn{3}{|c|}{ ASME Sec. IX Weld Qualification } \\
\hline & & & $X-R a y$ & Side Bend & RT Tensile \\
\hline W1 & $\begin{array}{l}\text { Low P }(<20 w p p m) \\
(011367-08), 0.064 " \text { dia }\end{array}$ & $\begin{array}{l}\text { AOD (140wppm P) } \\
\text { (58776-4B) }\end{array}$ & Pass & Pass & Pass \\
\hline $\mathbf{W} 2$ & $\begin{array}{c}\text { Low P }(<20 \text { wppm }) \\
(011367-08), 0.064 " \text { dia }\end{array}$ & $\begin{array}{l}\text { ESR (140wppm P) } \\
(58776-3 R B B)\end{array}$ & Pass & Pass & Pass \\
\hline W3 & $\begin{array}{l}\text { High P (140wppm) } \\
\text { 58776-4A1, 0.064” dia }\end{array}$ & $\begin{array}{l}\text { ESR (140wppm P) } \\
(58776-3 R B B)\end{array}$ & Failed & $\mathrm{N} / \mathrm{A}$ & N/A \\
\hline W4 & $\begin{array}{l}\text { High P (140wppm) } \\
\text { 58776-4A1, 0.064” dia }\end{array}$ & $\begin{array}{l}\text { ESR (140wppm P) } \\
(58776-3 R B B)\end{array}$ & Pass & Pass & Failed \\
\hline W5 & $\begin{array}{l}\text { High P (140wppm) } \\
\text { 58776-4A1, 0.045” dia }\end{array}$ & $\begin{array}{l}\text { ESR (140wppm P) } \\
(58776-3 R B B)\end{array}$ & Pass & Pass & Pass \\
\hline W6 & $\begin{array}{c}\text { Low P }(<20 w p p m) \\
(011367-08), 0.035 " \text { dia }\end{array}$ & $\begin{array}{l}\text { ESR (140wppm P) } \\
\text { 58776-3RBC-HT }\end{array}$ & Pass & Pass & TBD \\
\hline
\end{tabular}


Part of the weld qualification tests and weld microstructure characterization on welds W1-W4 was provided in previous report by Feng et al, 2019. This report provides additional results on the weld qualification test results of welds W5 and W6 in this section, and weld microstructure and initial creep testing results of selected welds in next sections, which were obtained after the last report.

\subsection{WELDING WITH HIGH P LEVEL WELD WIRE - WELD W5}

Previously, the welds (W3 and W4) fabricated with high P (140wppm) weld wire on the 140wppm P base metal (ESR 58776-3RBB) did not pass the SEME Section IX weld qualification test (Feng et al, 2019). W3 showed severe indications of weld defects under X-ray NDE, so no further qualification tests (side bend and room temperature tensile test) were carried out. Weld W4 passed the X-ray inspection and side bending test. However, it did not pass the room temperature tensile tests, and sub-mm sized cracks were found in the weld, predominately around the weld centerline associated with the final weld passes. In this reporting period, welding parameters were adjusted to lower the welding heat input, which is generally considered to be beneficial to reduce the solidification cracking.

\subsubsection{Welding of W5 Weld}

Two steps were taken to lower the welding heat input in welding Weld W5. First, the weld wire was reduced to a diameter of $1.626 \mathrm{~mm}(0.064 \mathrm{in})$ to $1.143 \mathrm{~mm}(0.045 \mathrm{in})$. Second hot-wire GTAW was used in which the weld wire was heated during welding. The basic weld joint configuration (single $\mathrm{V}$ groove butt weld) used for this W5 was the same as the weld W4 (Figure 1). The actual weld-pass layout to make W5 weld is schematically shown in Figure 2. There was a total of 34 welding passes. The welding parameters of W5 are shown in Table 3. There was no pre-heating of the base metal plate and the inter-pass temperature was kept below $100^{\circ} \mathrm{C}$. On average, the heat input for W5 was $28 \%$ lower than that for W4.

Photographs of W5 are shown in Figure 3. For Weld W5, the dimension of the plates were $185 \mathrm{~mm}$ (7.25in) long, $76 \mathrm{~mm}$ (3in) wide and $28.5 \mathrm{~mm}$ (1.125in) thick. The total length of the weld was $184 \mathrm{~mm}(7.25 \mathrm{in})$.

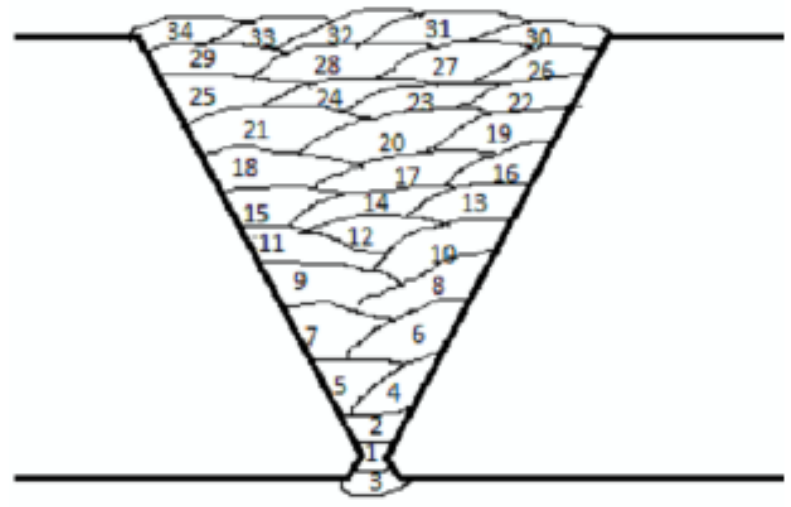

Figure 2. Actual weld-pass layout of W5 Weld. 
Table 3. Welding parameters for W5 weld (with 140wppm P weld wire)

\begin{tabular}{|c|c|c|c|c|c|c|c|c|c|c|c|c|}
\hline $\begin{array}{l}\text { Weld } \\
\text { pass }\end{array}$ & welding process & & d wire & $\begin{array}{c}\text { preheat } \\
\text { interpass temp } \\
\text { degrees C }\end{array}$ & $\begin{array}{l}\text { Volts }(\mathrm{V}) \\
\max \end{array}$ & $\operatorname{Amps}(A)$ & $\begin{array}{l}\text { Travel speed } \\
\quad \text { (ipm) }\end{array}$ & $\begin{array}{c}\text { ASME IX QW } 409.1 \text { (a) } \\
\text { Joules/inch }= \\
\left.\text { (Voltage* } \text { Amps }^{*} 60\right)\end{array}$ & $\mathrm{kJ} / \mathrm{inch}$ & $\begin{array}{l}\text { Wire feed speed } \\
\text { (ipm) automatic } \\
\text { or machine only }\end{array}$ & $\begin{array}{l}\text { string or weave, } \\
\text { weave enter } \\
\text { amplitude }\end{array}$ & notes \\
\hline 1 & $\begin{array}{c}\text { GTAW-HTW Manual, semi- } \\
\text { automatic }\end{array}$ & $0.045 " 709$ & Ht\# 58776-4 & $\begin{array}{l}\mathrm{N} / \mathrm{A}(23 \mathrm{C} \\
\text { ambient) }\end{array}$ & 12 & 120 & 4.4 & 19636.4 & 19.6 & 58 & weave $1 / 16$ & $\begin{array}{l}100 \text { Argon at } 35 \text { CFH and } \\
\text { backing gas }\end{array}$ \\
\hline 2 & $\begin{array}{c}\text { GTAW-HTW Manual, semi- } \\
\text { automatic }\end{array}$ & $0.045 " 709$ & Ht\# 58776-4 & $<100 \mathrm{C}$ & 13 & 180 & 4.1 & 34243.9 & 34.2 & 42 & weave $1 / 16$ & $\begin{array}{l}100 \text { Argon at } 35 \mathrm{CFH} \text { and } \\
\text { backing gas }\end{array}$ \\
\hline 3 & $\begin{array}{c}\text { GTAW-HTW Manual, semi- } \\
\text { automatic }\end{array}$ & $0.045 " 709$ & 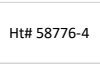 & $<100 \mathrm{C}$ & 14 & 185 & 5.3 & 29320.8 & 29.3 & 42 & Stringer & $\begin{array}{l}100 \text { Argon at } 35 \text { CFH and } \\
\text { backing gas back grind pass } 1 \\
\text { then back weld. }\end{array}$ \\
\hline 4 & $\begin{array}{c}\text { GTAW-HTW Manual, semi- } \\
\text { automatic }\end{array}$ & $0.045 " 709$ & $\mathrm{Ht \#}$ 58776-4 & $<100 \mathrm{C}$ & 14 & 185 & 6.6 & 23545.5 & 23.5 & 42 & Stringer & 100 Argon at $35 \mathrm{CFH}$ \\
\hline 5 & $\begin{array}{l}\text { GTAW-HTW Manual, semi- } \\
\text { automatic }\end{array}$ & $0.045 " 709$ & Ht\# 58776-4 & $<100 \mathrm{C}$ & 14 & 185 & 6.2 & 25064.5 & 25.1 & 42 & Stringer & 100 Argon at $35 \mathrm{CFH}$ \\
\hline 6 & $\begin{array}{l}\text { GTAW-HTW Manual, semi- } \\
\text { automatic }\end{array}$ & $0.045 " 709$ & Ht\# 58776-4 & $<100 \mathrm{C}$ & 14 & 185 & 5.9 & 26339.0 & 26.3 & 49 & Stringer & 100 Argon at $35 \mathrm{CFH}$ \\
\hline 7 & $\begin{array}{l}\text { GTAW-HTW Manual, semi- } \\
\text { automatic }\end{array}$ & $0.045 " 709$ & $\mathrm{Ht \#}$ 58776-4 & $<100 \mathrm{C}$ & 14 & 185 & 5.9 & 26339.0 & 26.3 & 49 & Stringer & 100 Argon at $35 \mathrm{CFH}$ \\
\hline 8 & $\begin{array}{l}\text { GTAW-HTW Manual, semi- } \\
\text { automatic }\end{array}$ & $0.045 " 709$ & Ht\# 58776-4 & $<100 \mathrm{C}$ & 14 & 185 & 5.6 & 27750.0 & 27.8 & 49 & Stringer & 100 Argon at $35 \mathrm{CFH}$ \\
\hline 9 & $\begin{array}{l}\text { GTAW-HTW Manual, semi- } \\
\text { automatic }\end{array}$ & $0.045 " 709$ & Ht\# 58776-4 & $<100 \mathrm{C}$ & 14 & 185 & 5.0 & 31080.0 & 31.1 & 49 & Stringer & 100 Argon at $35 \mathrm{CFH}$ \\
\hline 10 & $\begin{array}{l}\text { GTAW-HTW Manual, semi- } \\
\text { automatic }\end{array}$ & $0.045 " 709$ & Ht\# 58776-4 & $<100 \mathrm{C}$ & 14 & 185 & 5.0 & 31080.0 & 31.1 & 49 & Stringer & 100 Argon at 35 CFH \\
\hline 11 & $\begin{array}{l}\text { GTAW-HTW Manual, semi- } \\
\text { automatic }\end{array}$ & $0.045 " 709$ & Ht\# 58776-4 & $<100 \mathrm{C}$ & 14 & 185 & 5.3 & 29320.8 & 29.3 & 49 & Stringer & 100 Argon at $35 \mathrm{CFH}$ \\
\hline 12 & $\begin{array}{c}\text { GTAW-HTW Manual, semi- } \\
\text { automatic }\end{array}$ & $0.045 " 709$ & Ht\# 58776-4 & $<100 \mathrm{C}$ & 14 & 185 & 6.6 & 23545.5 & 23.5 & 49 & Stringer & 100 Argon at $35 \mathrm{CFH}$ \\
\hline 13 & $\begin{array}{l}\text { GTAW-HTW Manual, semi- } \\
\text { automatic }\end{array}$ & $0.045 " 709$ & $\mathrm{Ht \#} \mathrm{58776-4}$ & $<100 \mathrm{C}$ & 14 & 185 & 5.3 & 29320.8 & 29.3 & 49 & Stringer & 100 Argon at $35 \mathrm{CFH}$ \\
\hline 14 & $\begin{array}{c}\text { GTAW-HTW Manual, semi- } \\
\text { automatic }\end{array}$ & $0.045 " 709$ & Ht\# 58776-4 & $<100 \mathrm{C}$ & 14 & 185 & 6.6 & 23545.5 & 23.5 & 49 & Stringer & 100 Argon at $35 \mathrm{CFH}$ \\
\hline 15 & $\begin{array}{l}\text { GTAW-HTW Manual, semi- } \\
\text { automatic }\end{array}$ & $0.045 " 709$ & Ht\# 58776-4 & $<100 \mathrm{C}$ & 14 & 185 & 5.5 & 28254.5 & 28.3 & 49 & Stringer & 100 Argon at $35 \mathrm{CFH}$ \\
\hline 16 & $\begin{array}{c}\text { GTAW-HTW Manual, semi- } \\
\text { automatic }\end{array}$ & $0.045 " 709$ & $\mathrm{Ht \#} \mathrm{58776-4}$ & $<100 \mathrm{C}$ & 14 & 185 & 5.7 & 27263.2 & 27.3 & 49 & Stringer & 100 Argon at $35 \mathrm{CFH}$ \\
\hline 17 & $\begin{array}{l}\text { GTAW-HTW Manual, semi- } \\
\text { automatic }\end{array}$ & $0.045 " 709$ & Ht\# 58776-4 & $<100 \mathrm{C}$ & 14 & 185 & 7.0 & 22200.0 & 22.2 & 49 & Stringer & 100 Argon at $35 \mathrm{CFH}$ \\
\hline 18 & $\begin{array}{l}\text { GTAW-HTW Manual, semi- } \\
\text { automatic }\end{array}$ & $0.045 " 709$ & $\mathrm{Ht \#} \mathrm{58776-4}$ & $<100 \mathrm{C}$ & 14 & 185 & 5.7 & 27263.2 & 27.3 & 49 & Stringer & 100 Argon at $35 \mathrm{CFH}$ \\
\hline 19 & $\begin{array}{l}\text { GTAW-HTW Manual, semi- } \\
\text { automatic }\end{array}$ & $0.045 " 709$ & Ht\# 58776-4 & $<100 \mathrm{C}$ & 14 & 185 & 5.3 & 29320.8 & 29.3 & 49 & Stringer & 100 Argon at $35 \mathrm{CFH}$ \\
\hline 20 & $\begin{array}{l}\text { GTAW-HTW Manual, semi- } \\
\text { automatic }\end{array}$ & $0.045 " 709$ & $\mathrm{Ht \#}$ 58776-4 & $<100 \mathrm{C}$ & 14 & 185 & 5.9 & 26339.0 & 26.3 & 49 & Stringer & 100 Argon at $35 \mathrm{CFH}$ \\
\hline 21 & $\begin{array}{l}\text { GTAW-HTW Manual, semi- } \\
\text { automatic }\end{array}$ & $0.045 " 709$ & Ht\# 58776-4 & $<100 \mathrm{C}$ & 13 & 185 & 4.4 & 32795.5 & 32.8 & 49 & Stringer & 100 Argon at $35 \mathrm{CFH}$ \\
\hline 22 & $\begin{array}{c}\text { GTAW-HTW Manual, semi- } \\
\text { automatic }\end{array}$ & $0.045 " 709$ & Ht\# 58776-4 & $<100 \mathrm{C}$ & 13 & 185 & 5.9 & 24457.6 & 24.5 & 53 & Stringer & 100 Argon at $35 \mathrm{CFH}$ \\
\hline 23 & $\begin{array}{l}\text { GTAW-HTW Manual, semi- } \\
\text { automatic }\end{array}$ & $0.045 " 709$ & Ht\# 58776-4 & $<100 \mathrm{C}$ & 13 & 185 & 5.7 & 25315.8 & 25.3 & 53 & Stringer & 100 Argon at $35 \mathrm{CFH}$ \\
\hline 24 & $\begin{array}{l}\text { GTAW-HTW Manual, semi- } \\
\text { automatic }\end{array}$ & $0.045 " 709$ & Ht\# 58776-4 & $<100 \mathrm{C}$ & 13 & 185 & 5.7 & 25315.8 & 25.3 & 53 & Stringer & 100 Argon at $35 \mathrm{CFH}$ \\
\hline 25 & $\begin{array}{l}\text { GTAW-HTW Manual, semi- } \\
\text { automatic }\end{array}$ & $0.045 " 709$ & Ht\# 58776-4 & $<100 \mathrm{C}$ & 13 & 185 & 5.0 & 28860.0 & 28.9 & 53 & Stringer & 100 Argon at $35 \mathrm{CFH}$ \\
\hline 26 & $\begin{array}{l}\text { GTAW-HTW Manual, semi- } \\
\text { automatic }\end{array}$ & $0.045 " 709$ & Ht\# 58776-4 & $<100 \mathrm{C}$ & 13 & 185 & 5.6 & 25767.9 & 25.8 & 53 & Stringer & $100 \mathrm{Argon}$ at $35 \mathrm{CFH}$ \\
\hline 27 & $\begin{array}{l}\text { GTAW-HTW Manual, semi- } \\
\text { automatic }\end{array}$ & $0.045 " 709$ & Ht\# 58776-4 & $<100 \mathrm{C}$ & 13 & 185 & 6.2 & 23274.2 & 23.3 & 53 & Stringer & 100 Argon at $35 \mathrm{CFH}$ \\
\hline 28 & $\begin{array}{c}\text { GTAW-HTW Manual, semi- } \\
\text { automatic }\end{array}$ & $0.045 " 709$ & Ht\# 58776-4 & $<100 \mathrm{C}$ & 13 & 185 & 6.2 & 23274.2 & 23.3 & 53 & Stringer & $100 \mathrm{Argon}$ at $35 \mathrm{CFH}$ \\
\hline 29 & $\begin{array}{l}\text { GTAW-HTW Manual, semi- } \\
\text { automatic }\end{array}$ & $0.045 " 709$ & Ht\# 58776-4 & $<100 \mathrm{C}$ & 13 & 185 & 6.6 & 21863.6 & 21.9 & 53 & Stringer & 100 Argon at $35 \mathrm{CFH}$ \\
\hline 30 & $\begin{array}{l}\text { GTAW-HTW Manual, semi- } \\
\text { automatic }\end{array}$ & $0.045 " 709$ & Ht\# 58776-4 & $<100 \mathrm{C}$ & 13 & 185 & 5.9 & 24457.6 & 24.5 & 53 & Stringer & 100 Argon at $35 \mathrm{CFH}$ \\
\hline 31 & $\begin{array}{l}\text { GTAW-HTW Manual, semi- } \\
\text { automatic }\end{array}$ & $0.045 " 709$ & Ht\# 58776-4 & $<100 \mathrm{C}$ & 13 & 185 & 6.5 & 22200.0 & 22.2 & 53 & Stringer & 100 Argon at $35 \mathrm{CFH}$ \\
\hline 32 & $\begin{array}{l}\text { GTAW-HTW Manual, semi- } \\
\text { automatic }\end{array}$ & $0.045 " 709$ & Ht\# 58776-4 & $<100 \mathrm{C}$ & 13 & 185 & 5.8 & 24879.3 & 24.9 & 53 & Stringer & 100 Argon at $35 \mathrm{CFH}$ \\
\hline 33 & $\begin{array}{l}\text { GTAW-HTW Manual, semi- } \\
\text { automatic }\end{array}$ & $0.045 " 709$ & Ht\# 58776-4 & $<100 \mathrm{C}$ & 13 & 185 & 6.2 & 23274.2 & 23.3 & 53 & Stringer & 100 Argon at $35 \mathrm{CFH}$ \\
\hline 34 & $\begin{array}{c}\text { GTAW-HTW Manual, semi- } \\
\text { automatic }\end{array}$ & $0.045 " 709$ & Ht\# 58776-4 & $<100 \mathrm{C}$ & 13 & 185 & 7.5 & 19240.0 & 19.2 & 53 & Stringer & 100 Argon at $35 \mathrm{CFH}$ \\
\hline
\end{tabular}

\subsubsection{Code qualification testing of W5 weld}

The baseline weld qualification testing included X-ray inspection, side bend and room temperature crossweld tensile per ASME section IX. X-ray inspection result performed on W5 is shown in Figure 4. The W5 was found to be acceptable.

Test specimens for side bend, room temperature tensile, high temperature creep and microstructure analysis were machined per the layout shown in Figure 5. The three side bend specimens had $9.53 \mathrm{~mm}$ (3/8 in) in thickness, and a photograph of the specimens after side bend testing are shown in Figure 6. Small cracks were noticed inside the fusion zone but the size of the cracks was small (less than $3 \mathrm{~mm}$ ), which was acceptable per ASME section IX code requirement. 


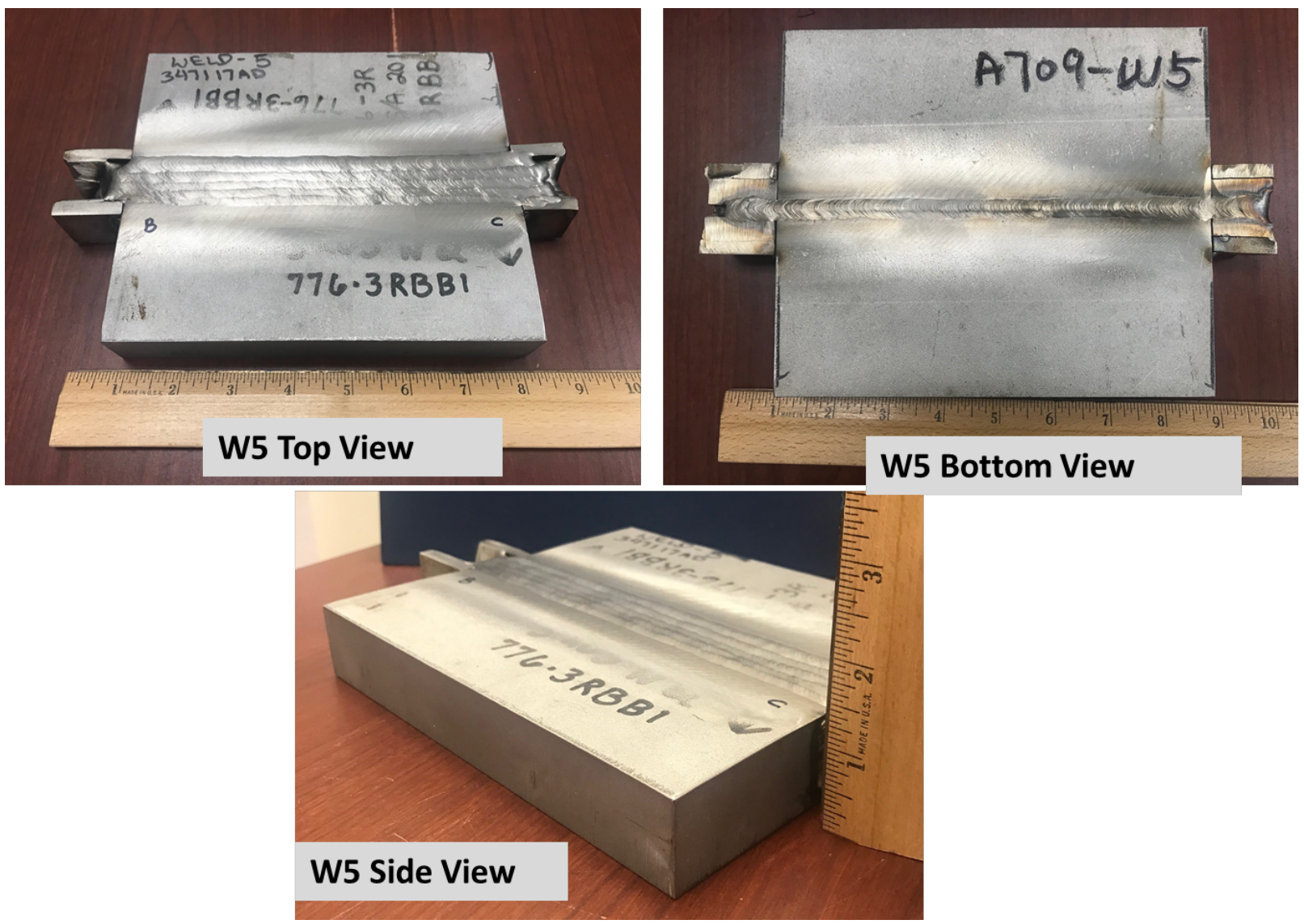

Figure 3. Appearance of W5 weld.

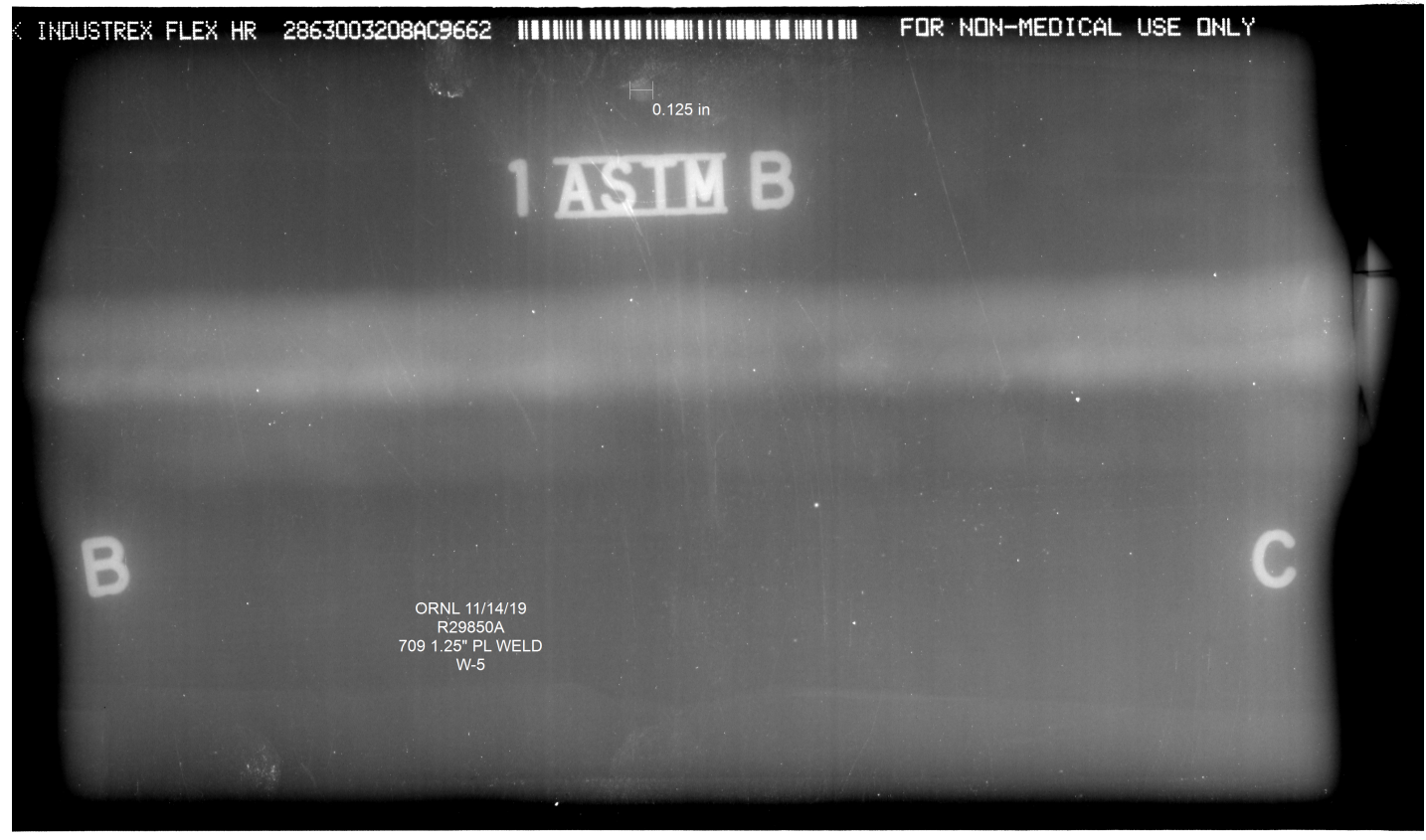

Figure 4. X-ray inspection result of W5 weld 


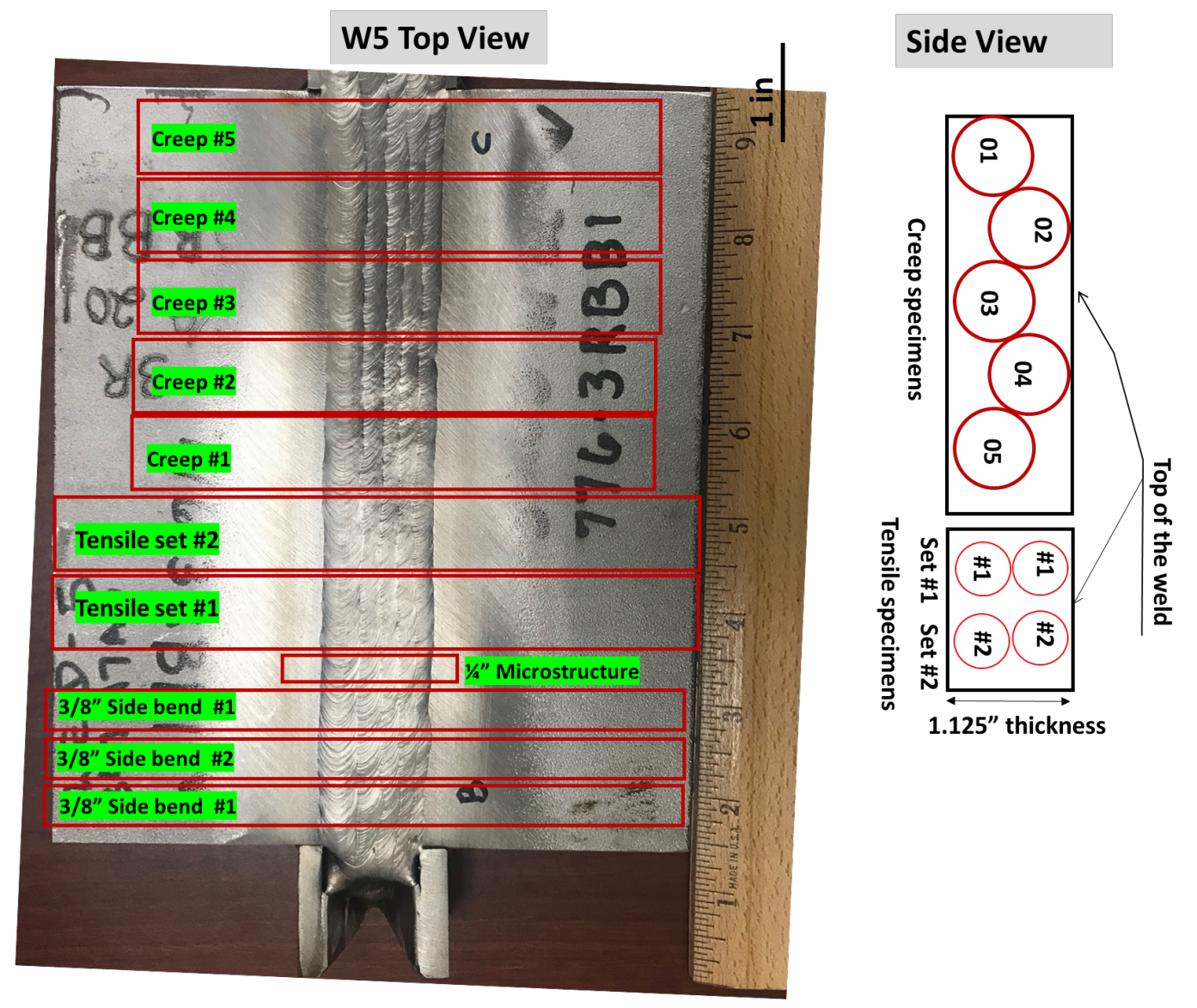

Figure 5. Layout of the test specimens from Weld W5.

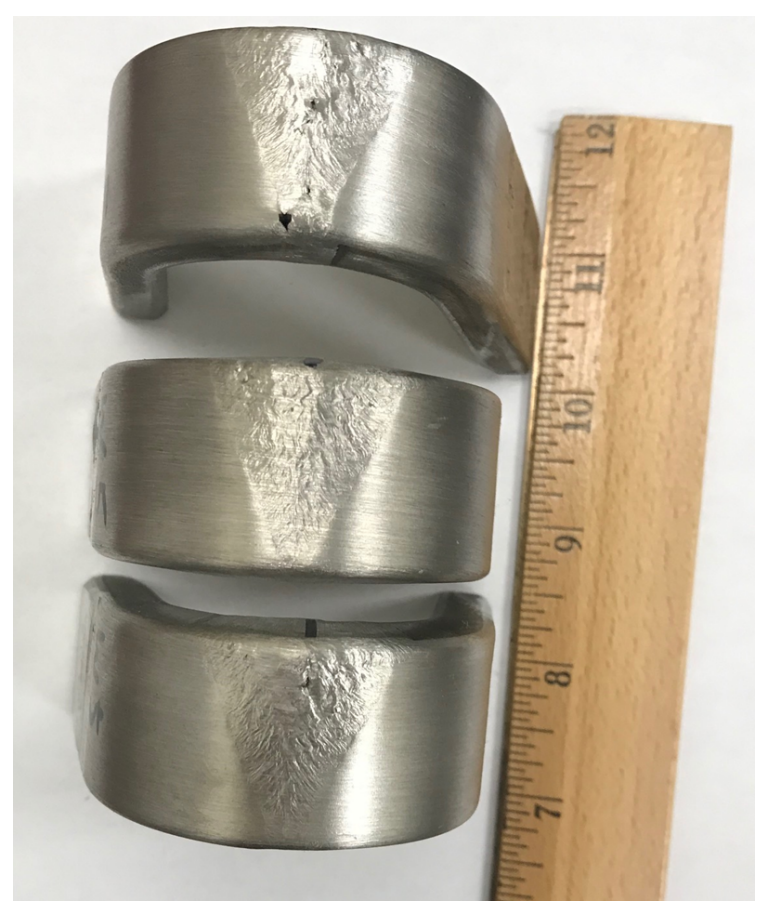

Figure 6. Side bend test results of Weld W5 
Two sets of cross-weld tensile test specimens were machined from Weld W5. The locations of the tensile specimens are shown in Figure 5. Each set of the tensile tests had one specimen out of the top of the weld and one out of the bottom of the weld. The room temperature tensile stress-strain curves are plotted in Figure 7. The tensile strengths of the four test specimens are summarized in Table 4 . The tensile strengths of all four specimens were above the minimum ASME code required base metal tensile strength of $640 \mathrm{MPa}$, and the failure was ductile with failure located inside the weldment. As such, Weld W5 passed the ASME section IX weld quality requirement test. It should be noted that the top half of the weld consistently had lower tensile strength than the bottom half of the weld.

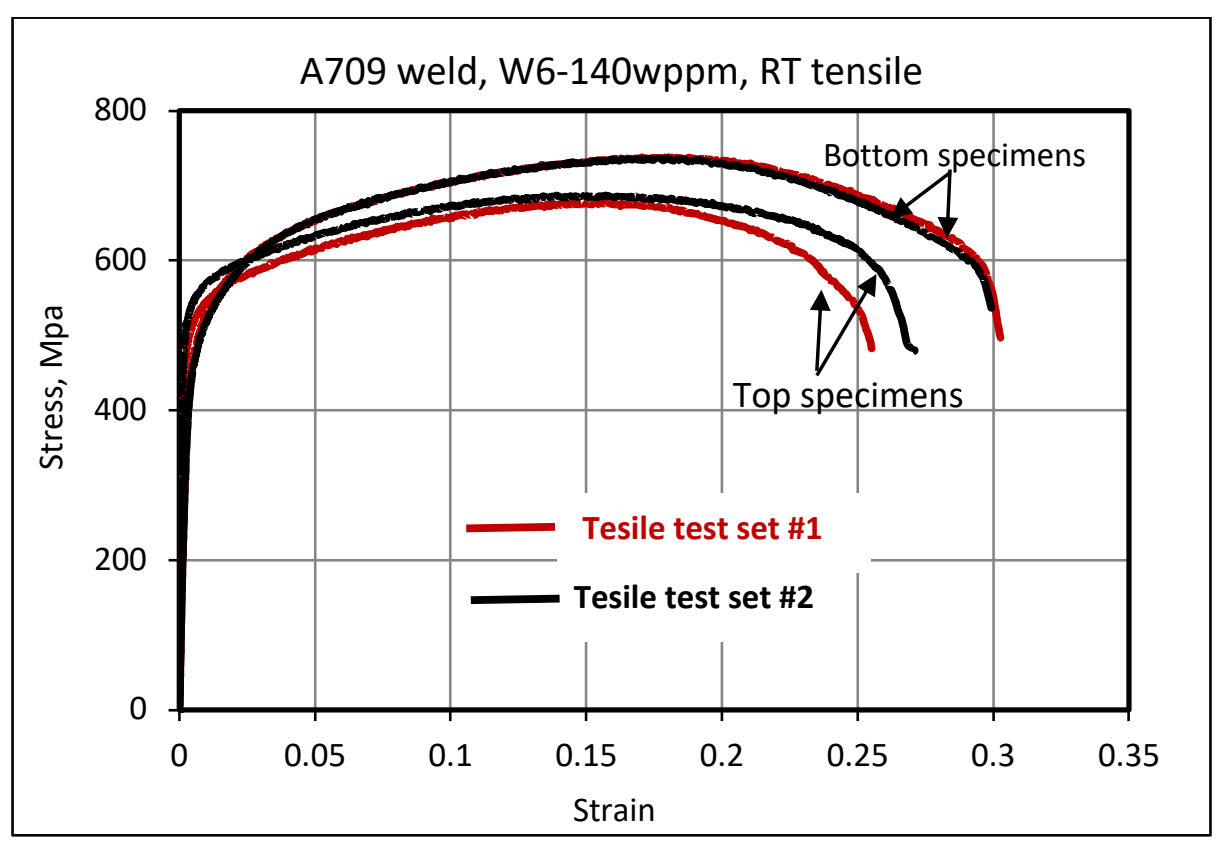

Figure 7. Room temperature cross-weld tensile results for 709 weld W5

Table 4. Room temperature cross-weld tensile results for 709 weld W5

\begin{tabular}{l|l|l}
\hline & Location of the tensile specimens & $\begin{array}{l}\text { Tensile strength, } \\
\text { MPa }\end{array}$ \\
\hline \multirow{2}{*}{$\begin{array}{l}\text { Cross-weld tensile } \\
\text { test set } \# 1\end{array}$} & Top of the weld & 678.4 \\
\cline { 2 - 3 } $\begin{array}{l}\text { Cross-weld tensile } \\
\text { test set } \# 2\end{array}$ & Bottom of the weld & 739.3 \\
\cline { 2 - 3 } & Top of the weld & 688.2 \\
\hline
\end{tabular}




\subsection{WELDING WITH LOW P LEVEL WELD WIRE - WELD W6}

As reported previously (Feng, 2019), the commercial Alloy 709 heat with relatively high P level of 140wppm was successfully welded using welding wire having <20wppm P - Welds W1 and W2 in Table 2 which are solution annealed at $1100^{\circ} \mathrm{C}$. However, research on the high temperature mechanical properties of Alloy 709 base metal concluded that an additional aging heat treatment step at $775^{\circ} \mathrm{C}$ for 10 hr (Mike's 2019?) notably improved the material creep-fatigue performance while not significantly affecting the creep resistance. As the welding thermal cycle may alter the microstructure constituents such as the precipitates formed during the aging heat treatment, it is necessary to re-evaluate the weld quality and its high temperature mechanical properties after the aging heat treatment.

\subsubsection{Welding of W6 Weld}

Weld W6 was fabricated on the heat treated ESR plates (58776-3RBC-HT). The weld wire had less than $20 \mathrm{wppm}$ P level, with reduced diameter of $0.899 \mathrm{~mm}(0.035 \mathrm{in})$, compared to $1.626 \mathrm{~mm}(0.064$ ") wire diameter for the $\mathrm{W} 2$ weld. The smaller wire diameter made it possible to further reduce the welding heat input without the use of hot wire technique. The single $\mathrm{V}$ groove butt weld was the same as all previous weld (Feng 2019), also shown in Figure 1. The actual weld-pass layout for W6 is schematically shown in Figure 8, which is similar to that of W5 with a total of 34 welding passes. The welding parameters of W6 weld are shown in Table 5. For the W6 weld, there was no pre-heating of the base metal plate nor the weld wire, and the interpass temperature was kept being below $100^{\circ} \mathrm{C}$. On average, the heat input for W6 weld was $32 \%$ lower than that of W2 weld fabricated with larger wire diameter of $1.63 \mathrm{~mm}(0.064 \mathrm{in})$. Photographs of W6 are shown in Figure 9. Same as the Weld W5, the dimension of the plates for Weld W6 were $185 \mathrm{~mm}$ (7.25in) long, $76 \mathrm{~mm}$ (3in) wide and $28.5 \mathrm{~mm}$ (1.125in) thick. The total length of the weld was $184 \mathrm{~mm}(7.25 \mathrm{in})$.

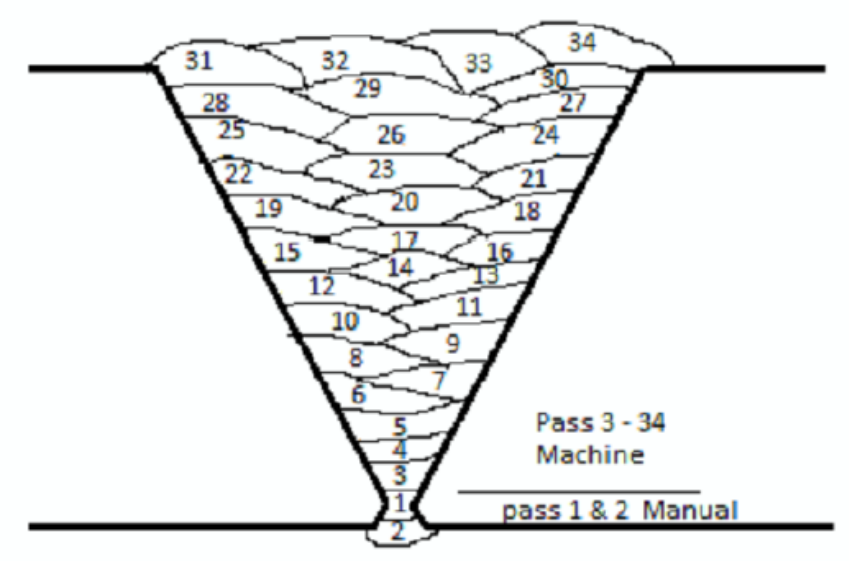

Figure 8. Actual weld-pass layout of W6 Weld 


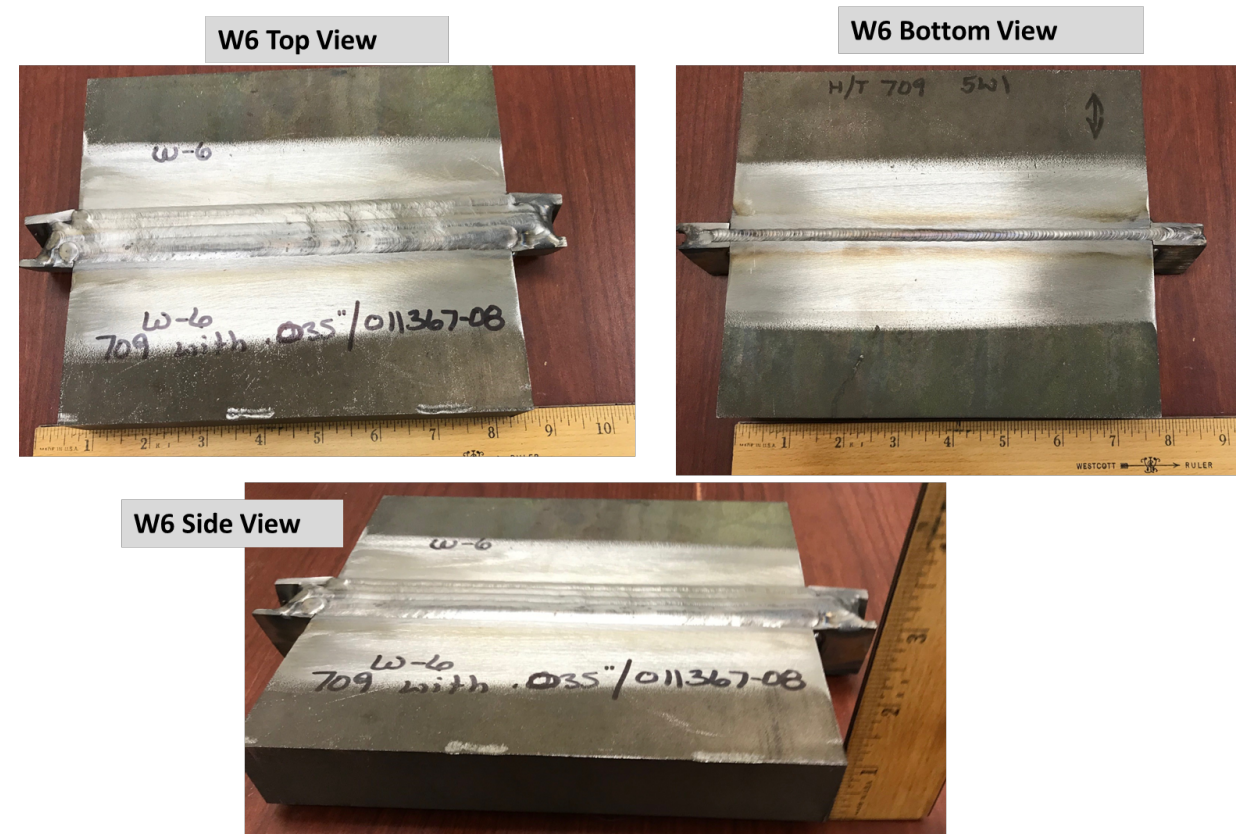

Figure 9. Appearance of W6 weld

Table 5. Welding parameters for W6 weld (with <20wppm P weld wire)

\begin{tabular}{|c|c|c|c|c|c|c|c|c|c|c|c|}
\hline $\begin{array}{l}\text { Weld } \\
\text { pass }\end{array}$ & welding process & Weld wire & $\begin{array}{c}\text { Preheat } \\
\text { interpass } \\
\text { temp } \\
\text { degrees C }\end{array}$ & $\begin{array}{c}\text { Volts (V) } \\
\max \end{array}$ & Amps (A) & $\begin{array}{l}\text { Travel } \\
\text { speed } \\
\text { (ipm) }\end{array}$ & $\begin{array}{c}\text { ASME IX QW } \\
409.1 \text { (a) } \\
\text { Joules/inch = } \\
\text { (Voltage* } \\
\text { Amps*60) / (ipm) }\end{array}$ & $\mathrm{kJ} /$ inch & $\begin{array}{l}\text { Wire feed } \\
\text { speed } \\
\text { (ipm) } \\
\text { automatic } \\
\text { or machine }\end{array}$ & $\begin{array}{c}\text { String or } \\
\text { weave, } \\
\text { weave } \\
\text { enter } \\
\text { amplitude }\end{array}$ & notes \\
\hline 1 & GTAW Manual & 0.063" 709, Ht\# 011367-08 (low-P) & $\begin{array}{l}\text { N/A (23 C } \\
\text { ambient) }\end{array}$ & 8.5 & 75 & 3.0 & 12750.0 & 12.8 & N/A & stringer & $\begin{array}{c}\text { backing weld pass } 1,100 \\
\text { Argon at } 35 \text { CFH and } \\
\text { backing gas }\end{array}$ \\
\hline 2 & GTAW Manual & 0.063" 709, Ht\# 011367-08 (low-P) & $<100 \mathrm{C}$ & 10.1 & 101 & 4.9 & 12491.0 & 12.5 & N/A & stringer & $\begin{array}{c}\text { backing weld pass } 2,100 \\
\text { Argon at } 35 \mathrm{CFH} \text { and } \\
\text { backing gas }\end{array}$ \\
\hline 3 & GTAW Machine & 0.035" 709, Ht\# 011367-08 (low-P) & $<100 \mathrm{C}$ & 9.8 & 160 & 5.0 & 18816.0 & 18.8 & 40 & Stringer & $\begin{array}{l}100 \text { Argon at } 35 \text { CFH and } \\
\text { backing gas back grind } \\
\text { pass } 1 \text { then weld }\end{array}$ \\
\hline 4 & GTAW Machine & 0.035" 709, Ht\# 011367-08 (low-P) & $<100 \mathrm{C}$ & 10 & 165 & 5.0 & 19800.0 & 19.8 & 45 & Stringer & 100 Argon at $35 \mathrm{CFH}$ \\
\hline 5 & GTAW Machine & $0.035 " 709, \mathrm{Ht \#} 011367-08$ (low-P) & $<100 \mathrm{C}$ & 10.2 & 170 & 5.0 & 20808.0 & 20.8 & 60 & Stringer & 100 Argon at $35 \mathrm{CFH}$ \\
\hline 6 & GTAW Machine & $0.035 " 709, \mathrm{Ht \#} 011367-08$ (low-P) & $<100 \mathrm{C}$ & 10 & 160 & 5.0 & 19200.0 & 19.2 & 50 & Stringer & 100 Argon at $35 \mathrm{CFH}$ \\
\hline 7 & GTAW Machine & 0.035" 709, Ht\# 011367-08 (low-P) & $<100 \mathrm{C}$ & 10 & 165 & 5.0 & 19800.0 & 19.8 & 50 & Stringer & 100 Argon at $35 \mathrm{CFH}$ \\
\hline 8 & GTAW Machine & 0.035" 709, Ht\# 011367-08 (low-P) & $<100 \mathrm{C}$ & 10.3 & 170 & 5.0 & 21012.0 & 21.0 & 60 & Stringer & 100 Argon at $35 \mathrm{CFH}$ \\
\hline 9 & GTAW Machine & 0.035" 709, Ht\# 011367-08 (low-P) & $<100 \mathrm{C}$ & 10.3 & 170 & 5.0 & 21012.0 & 21.0 & 60 & Stringer & 100 Argon at $35 \mathrm{CFH}$ \\
\hline 10 & GTAW Machine & $0.035 " 709, \mathrm{Ht \#} 011367-08$ (low-P) & $<100 \mathrm{C}$ & 10.3 & 170 & 5.0 & 21012.0 & 21.0 & 60 & Stringer & 100 Argon at $35 \mathrm{CFH}$ \\
\hline 11 & GTAW Machine & $0.035 " 709, \mathrm{Ht \#} 011367-08$ (low-P) & $<100 \mathrm{C}$ & 10.4 & 170 & 5.0 & 21216.0 & 21.2 & 60 & Stringer & 100 Argon at $35 \mathrm{CFH}$ \\
\hline 12 & GTAW Machine & $0.035 " 709, \mathrm{Ht \#} 011367-08$ (low-P) & $<100 \mathrm{C}$ & 10.4 & 175 & 5.0 & 21840.0 & 21.8 & 65 & Stringer & 100 Argon at $35 \mathrm{CFH}$ \\
\hline 13 & GTAW Machine & $0.035 " 709, \mathrm{Ht \#} 011367-08$ (low-P) & $<100 \mathrm{C}$ & 10.5 & 175 & 5.0 & 22050.0 & 22.1 & 65 & Stringer & 100 Argon at $35 \mathrm{CFH}$ \\
\hline 14 & GTAW Machine & 0.035" 709, Ht\# 011367-08 (low-P) & $<100 \mathrm{C}$ & 10.6 & 175 & 5.0 & 22260.0 & 22.3 & 70 & Stringer & 100 Argon at $35 \mathrm{CFH}$ \\
\hline 15 & GTAW Machine & 0.035" 709, Ht\# 011367-08 (low-P) & $<100 \mathrm{C}$ & 10.6 & 175 & 5.0 & 22260.0 & 22.3 & 70 & Stringer & 100 Argon at $35 \mathrm{CFH}$ \\
\hline 16 & GTAW Machine & 0.035" 709, Ht\# 011367-08 (low-P) & $<100 \mathrm{C}$ & 10.6 & 175 & 5.0 & 22260.0 & 22.3 & 70 & Stringer & 100 Argon at $35 \mathrm{CFH}$ \\
\hline 17 & GTAW Machine & 0.035" 709, Ht\# 011367-08 (low-P) & $<100 \mathrm{C}$ & 10.4 & 175 & 5.0 & 21840.0 & 21.8 & 70 & Stringer & 100 Argon at $35 \mathrm{CFH}$ \\
\hline 18 & GTAW Machine & 0.035" 709, Ht\# 011367-08 (low-P) & $<100 \mathrm{C}$ & 10.4 & 175 & 5.0 & 21840.0 & 21.8 & 75 & Stringer & 100 Argon at $35 \mathrm{CFH}$ \\
\hline 19 & GTAW Machine & 0.035" 709, Ht\# 011367-08 (low-P) & $<100 \mathrm{C}$ & 10.4 & 175 & 5.0 & 21840.0 & 21.8 & 75 & Stringer & 100 Argon at $35 \mathrm{CFH}$ \\
\hline 20 & GTAW Machine & 0.035" 709, Ht\# 011367-08 (low-P) & $<100 \mathrm{C}$ & 10.4 & 180 & 5.0 & 22464.0 & 22.5 & 75 & Stringer & 100 Argon at $35 \mathrm{CFH}$ \\
\hline 21 & GTAW Machine & 0.035" 709, Ht\# 011367-08 (low-P) & $<100 \mathrm{C}$ & 10.4 & 175 & 5.0 & 21840.0 & 21.8 & 75 & Stringer & 100 Argon at $35 \mathrm{CFH}$ \\
\hline 22 & GTAW Machine & 0.035" 709, Ht\# 011367-08 (low-P) & $<100 \mathrm{C}$ & 10.4 & 175 & 5.0 & 21840.0 & 21.8 & 75 & Stringer & 100 Argon at $35 \mathrm{CFH}$ \\
\hline 23 & GTAW Machine & 0.035" 709, Ht\# 011367-08 (low-P) & $<100 \mathrm{C}$ & 10.4 & 175 & 5.0 & 21840.0 & 21.8 & 70 & Stringer & 100 Argon at $35 \mathrm{CFH}$ \\
\hline 24 & GTAW Machine & 0.035" 709, Ht\# 011367-08 (low-P) & $<100 \mathrm{C}$ & 10.6 & 170 & 5.0 & 21624.0 & 21.6 & 70 & Stringer & 100 Argon at $35 \mathrm{CFH}$ \\
\hline 25 & GTAW Machine & 0.035" 709, Ht\# 011367-08 (low-P) & $<100 \mathrm{C}$ & 10.4 & 170 & 5.0 & 21216.0 & 21.2 & 70 & Stringer & 100 Argon at $35 \mathrm{CFH}$ \\
\hline 26 & GTAW Machine & 0.035" 709, Ht\# 011367-08 (low-P) & $<100 \mathrm{C}$ & 10.4 & 170 & 5.0 & 21216.0 & 21.2 & 70 & Stringer & 100 Argon at $35 \mathrm{CFH}$ \\
\hline 27 & GTAW Machine & 0.035" 709, Ht\# 011367-08 (low-P) & $<100 \mathrm{C}$ & 10.4 & 170 & 5.0 & 21216.0 & 21.2 & 70 & Stringer & 100 Argon at $35 \mathrm{CFH}$ \\
\hline 28 & GTAW Machine & 0.035" 709, Ht\# 011367-08 (low-P) & $<100 \mathrm{C}$ & 10.4 & 170 & 5.0 & 21216.0 & 21.2 & 70 & Stringer & 100 Argon at $35 \mathrm{CFH}$ \\
\hline 29 & GTAW Machine & 0.035" 709, Ht\# 011367-08 (low-P) & $<100 \mathrm{C}$ & 10.4 & 170 & 5.0 & 21216.0 & 21.2 & 70 & Stringer & 100 Argon at $35 \mathrm{CFH}$ \\
\hline 30 & GTAW Machine & 0.035" 709, Ht\# 011367-08 (low-P) & $<100 \mathrm{C}$ & 10.4 & 170 & 5.0 & 21216.0 & 21.2 & 60 & Stringer & 100 Argon at $35 \mathrm{CFH}$ \\
\hline 31 & GTAW Machine & 0.035" 709, Ht\# 011367-08 (low-P) & $<100 \mathrm{C}$ & 10.4 & 160 & 5.0 & 19968.0 & 20.0 & 60 & Stringer & 100 Argon at $35 \mathrm{CFH}$ \\
\hline 32 & GTAW Machine & 0.035" 709, Ht\# 011367-08 (low-P) & $<100 \mathrm{C}$ & 10.4 & 160 & 5.0 & 19968.0 & 20.0 & 60 & Stringer & 100 Argon at $35 \mathrm{CFH}$ \\
\hline 33 & GTAW Machine & 0.035" 709, Ht\# 011367-08 (low-P) & $<100 \mathrm{C}$ & 10.4 & 160 & 5.0 & 19968.0 & 20.0 & 60 & Stringer & 100 Argon at $35 \mathrm{CFH}$ \\
\hline 34 & GTAW Machine & $0.035 " 709, \mathrm{Ht \#} 011367-08$ (low-P) & $<100 \mathrm{C}$ & 10.4 & 160 & 5.0 & 19968.0 & 20.0 & 60 & Stringer & 100 Argon at $35 \mathrm{CFH}$ \\
\hline
\end{tabular}




\subsubsection{Code qualification testing of W5 weld}

X-ray inspection results of W6 weld are shown in Figure 10. The W6 was found to be acceptable per ASME Section IX. Three duplicate side-bend tests were performed. The results are shown in Figure 11. All three specimens showed no indications of any cracks in the weldment after the bend test. At the time of this report, cross-weld tensile specimens are being machined.

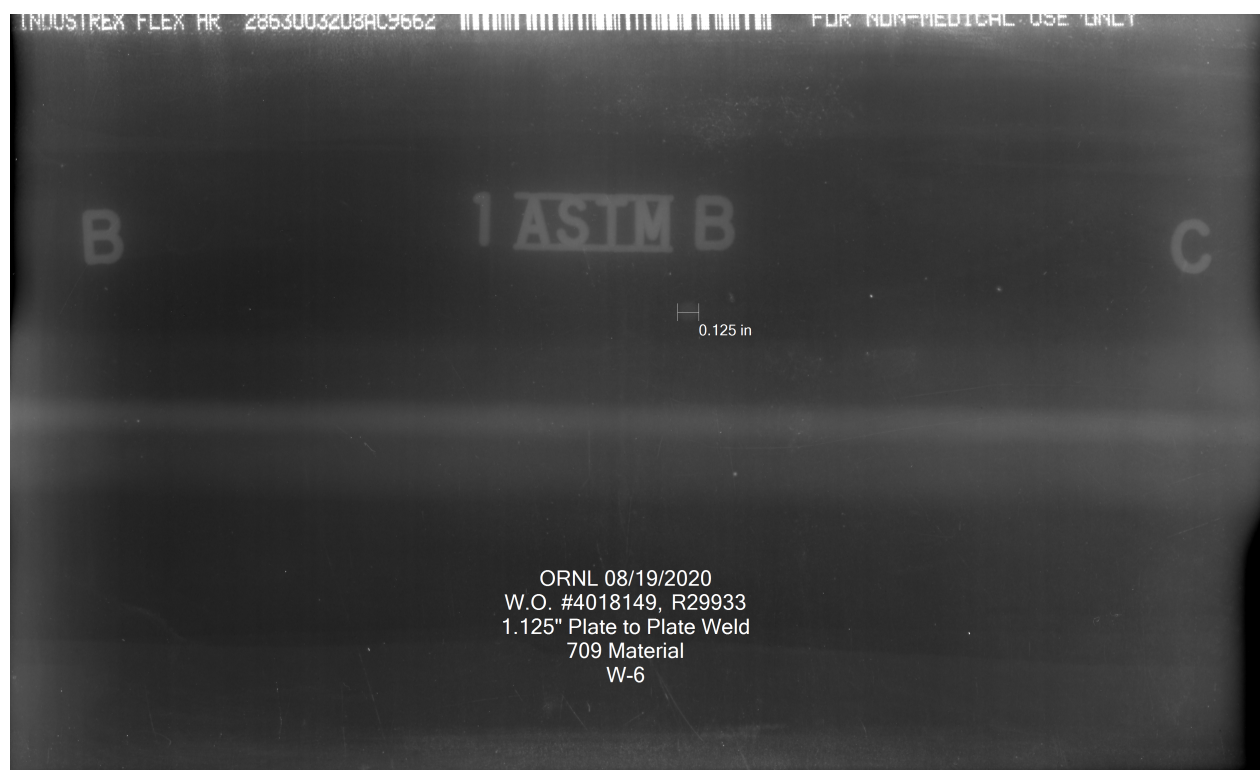

Figure 10. X-ray inspection of Weld W6

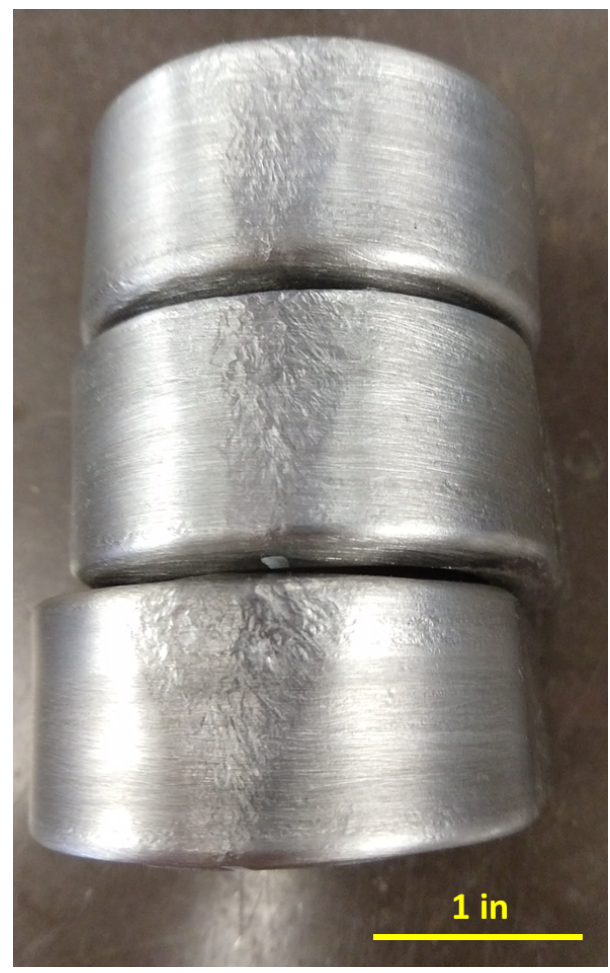

Figure 11. Side bend test results for Weld W6 


\section{MICROSTRUCTURE CHARATERIZATION}

\subsection{W4 WELD}

The W4 weld was made with high $\mathrm{P}$ weld wire at 140 wppm (58776-4A1) on the 140 wppm P commercial Carlson heat (ESR 58776-3RBB). While it passed the X-ray NDE, the dye penetrant inspection, the weld side bend tests showed visible cracks. These cracks are less than $3 \mathrm{~mm}(0.125$-in) in size, so technically the W4 weld passed the ASME Sec IX requirement for side bend weld qualification test. The room temperature cross-weld tensile tests showed that two specimens from the bottom half of the weld had repeatable results that passed the 640MPa specified minimum tensile strength for Alloy 709 per ASME Sec IX. On the other hand, the two specimens from the top half of weld failed prematurely and did not meet the minimum strength requirement. Thus, the W4 weld did not pass the ASME IX weld qualification requirements, on the basis of the low ultimate tensile strength of the "Top 2" weld specimen.

As reported in (Feng 2019), further examination of the W4 weld revealed a number of sub-mm cracks that were clustered top half of the weld, as shown in Figure 12. Under high magnification, these cracks resemble the characteristics of weld solidification cracking (Figure 13). The locations of cracks observed in the side bend test specimen were consistent with those of the sub-mm cracks. It is reasoned that these sub-mm solidification cracks were enlarged during the side bend test and became visible after the side bend test. In addition, the fracture surface of the "Top 2" tensile specimen showed characteristics of weld solidification cracks in contrast to the ductile fracture with dimple features of the "Bottom 2" tensile specimens. Therefore, the low tensile strength and reduced ductility of the specimens from the top of the weld are related to the solidification cracks and other micro-sized weld defects.

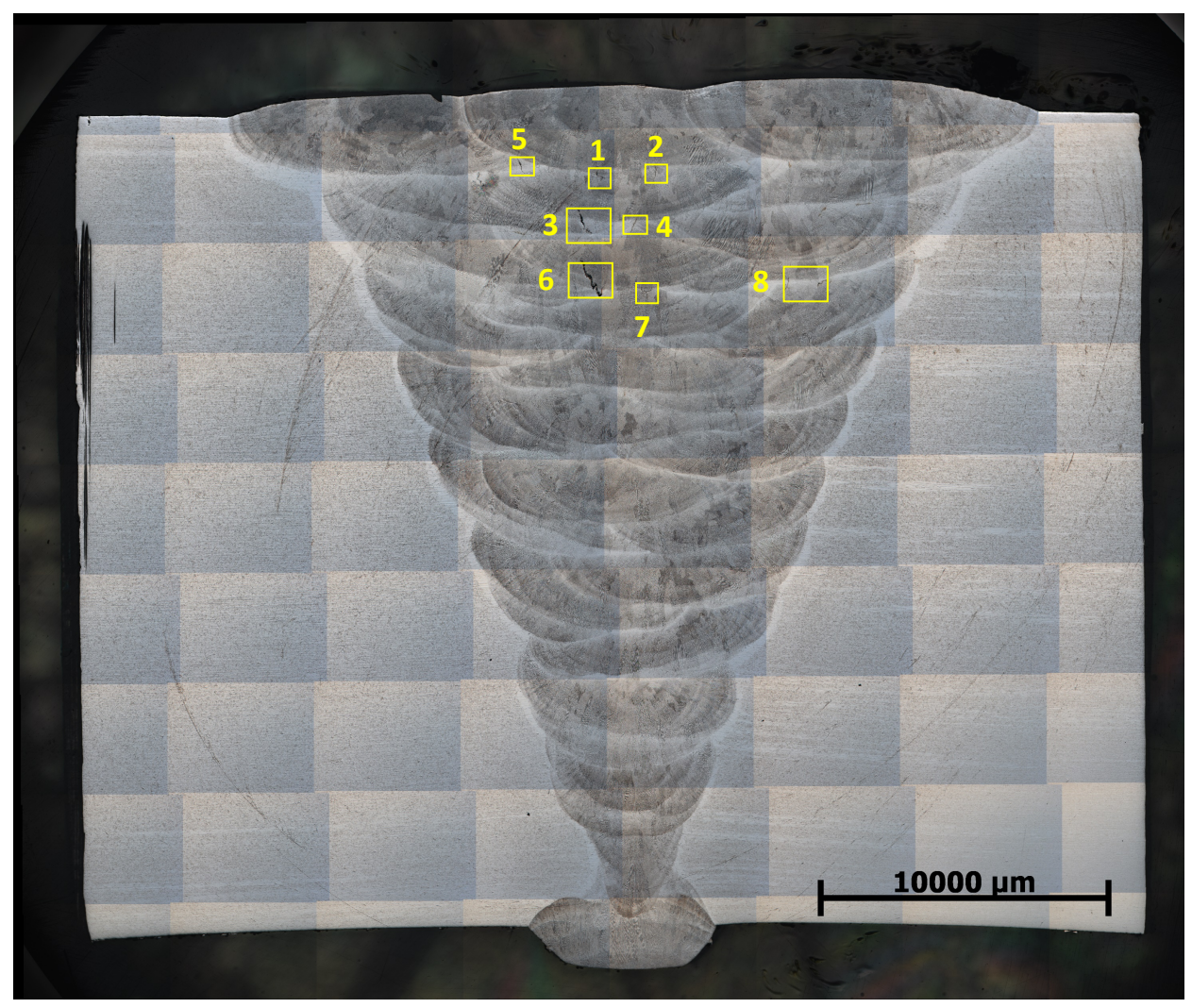

Figure 12. Cross-weld view of the W4 weld. Sub-mm weld cracks were found near the top section of the weld. 

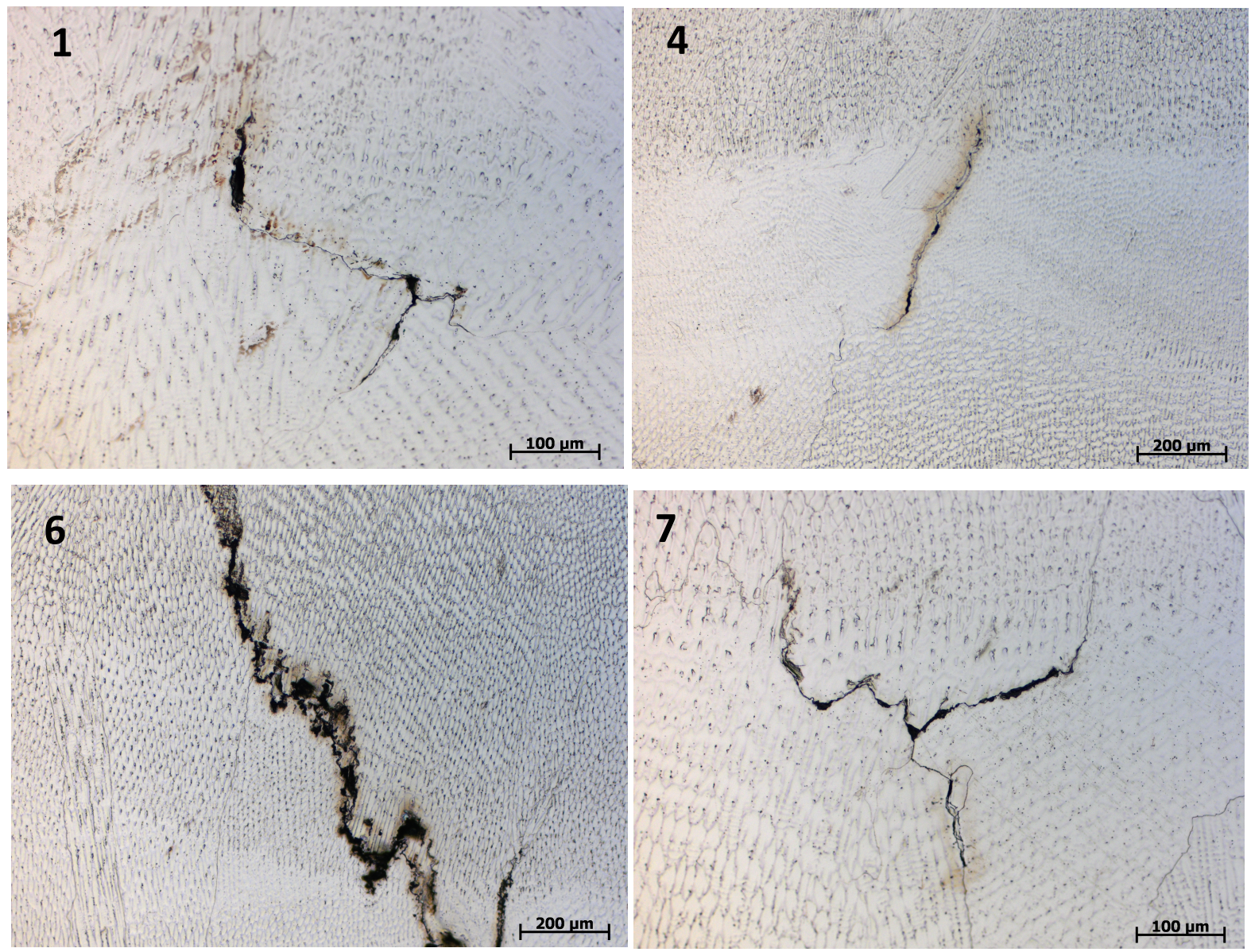

Figure 13. Solidification cracks in W4 welds. The ID of each photo correspond to those in Figure 12.

Computational solidification simulation modeling performed previously (Feng, et al. 2018) suggested that $\mathrm{P}$ segregation during weld solidification at high $\mathrm{P}$ level would significantly suppresses the solidus temperature and increase the susceptibility of solidification cracking in Alloy 709. In this report period, microstructure and micro-chemical analysis was performed to determine the $\mathrm{P}$ distribution and segregation behavior in W4 weld, primarily using electron probe micro-analyzer (EPMA) and electron backscatter diffraction (EBSD) mapping and line scans. The purpose of this analysis is to provide information on optimizing the welding techniques for Alloy 709.

EPMA line scan was conducted to determine the P distribution at three levels: macro-scale variation from one weld pass to next, meso-scale variation within a weld pass, and micro-scale segregation at grain or sub-grain level. The macro-scale and meso-scale $\mathrm{P}$ variation is shown in Figure 14. Two line scans along lines $\mathrm{AB}$ and $\mathrm{CD}$ were performed. The position of the line $\mathrm{AB}$ was along the weld centerline marked as the thin black line running through the weld top (cover pass) to the bottom (root pass). The position of the second line scan CD was marked as another thin black line running from the weld top to the fusion boundary and further extending into the base metal. The EPMA line-scans were conducted using a JEOL 8500 F Field Emission Electron Probe Microanalyzer with $60 \mu \mathrm{m}$ as the step size, $10 \mu \mathrm{m}$ as the beam size, $5 \mathrm{~min}$ as the dwell time. The white plots (dots and lines) are the measured data of $\mathrm{P}$ content and the red plots (dots) are the moving average of the P content over 5 measurement points of $300 \mu \mathrm{m}$ total distance.

As shown from the line scan results in in Figure 14, there are strong local variations in P content at the meso-scale level, i.e., within a weld pass. However, there appears no significant macro-scale $\mathrm{P}$ variation 
between different weld passes. In other words, the average or mean $\mathrm{P}$ level among different weld passes was relatively similar, about 140wppm - the P content of weld wires and the base metal in W4. No apparent macroscopic pass-to-pass $\mathrm{P}$ segregation was observed. It is also noted that the measurement along line $\mathrm{CD}$ extended to the base metal. As expected, $\mathrm{P}$ content in the base metal is rather uniform as averaged at 140wppm, the $\mathrm{P}$ level in the base metal.

It is reasoned that the locally high $\mathrm{P}$ content observed at the meso-scale with a weld pass might be caused by the $\mathrm{P}$ segregation at the grain boundaries as non-equilibrium solidification of the weld metal. Further study is on-going to directly measure the $\mathrm{P}$ distribution at higher spatial resolution at selected locations along lines $\mathrm{AB}$ and $\mathrm{CD}$, to confirm that these high $\mathrm{P}$ locations are indeed associated with the solidification grain boundaries.

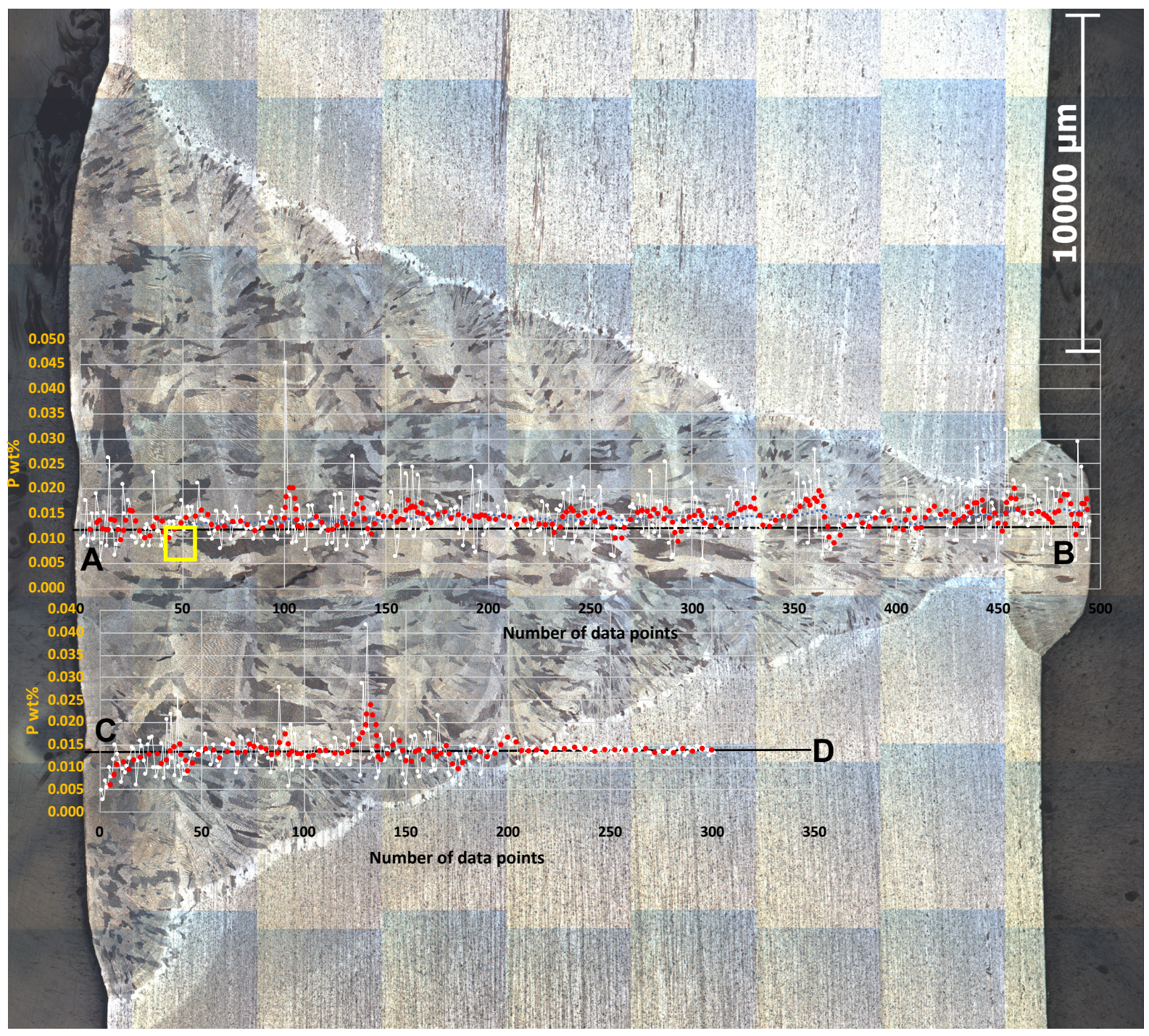

Figure 14. Macro-scale and meso-scale EPMA line scans across the multi-pass weld

In addition, micro-level EPMA mapping of $\mathrm{P}$ was performed around a small crack. The location of this micro-crack and P mapping region are marked by the yellow box in Figure 14. The micro-scale EMPA mapping covered an area of approximately $150 \times 100 \mu \mathrm{m}$ around the crack. The P concentration mapping results are shown in Figure 15. One grain boundary shows high $\mathrm{P}$ content and the crack shows high $\mathrm{P}$ 
content too. The EMPA mapping results provided the direct evidence of $\mathrm{P}$ segregation to the grain boundaries during welding of Alloy 709. According to the non-equilibrium solidification theory and computational simulation (Feng, Vitek, Liu, \& Wang, 2018), significant P segregation would only take place at the final stage of solidification. And not all grain boundaries in Figure 15 are formed during the final stage of solidification. Thus, it is reasonable that only one grain boundary in Figure 15 contains higher P content. It is also noted that, since it is very difficult to avoid the crack region be contaminated during SEM sample preparation, the apparent high $\mathrm{P}$ concentration at the crack region in the figure may not be a definitive confirmation of $\mathrm{P}$ segregation at the cracked grain boundary as a results of weld solidification.

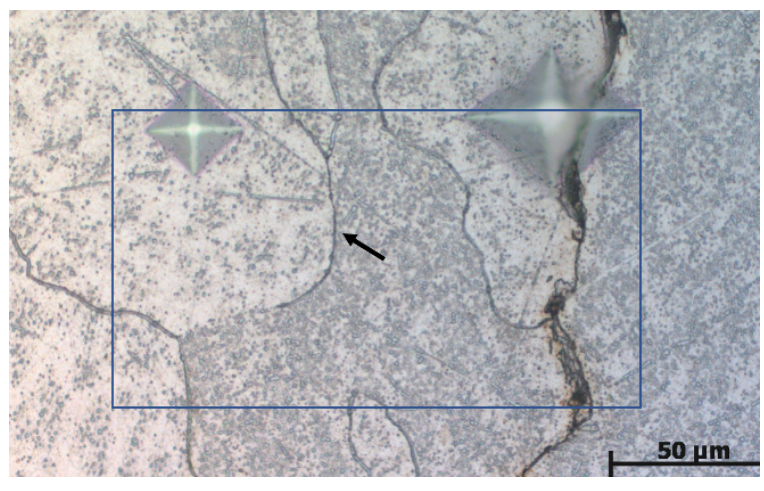

$\mathrm{a}$

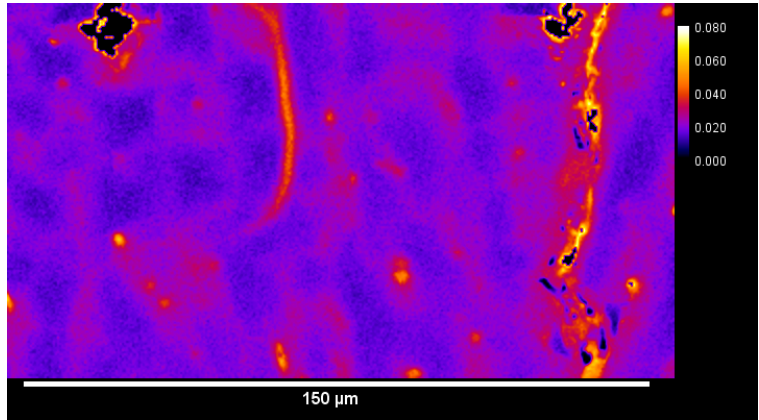

b

Figure 15. EPMA map scan covering grain boundaries and a crack

The EBSD mapping was conducted in a region marked with yellow frame in

Figure 16a. The region contains several sub-mm long cracks which are along the grain boundaries. Three line-scans a-b, c-d and e-f crossing the cracks give the misorientation profiles of the grains on two sides of the cracks. The misorientation of the two neighboring grains with the crack in between is around $40^{\circ}$, in the category of high angle grain boundary (HAGB) (

Figure 16. e, f and g). Thus, the cracks occurred along the HAGBs.

Figure $16 \mathrm{~h}$ shows the distribution of the HAGBs in the selected region. Around $73.3 \%$ of the grains are HAGBs with the misorientation $>15^{\circ}$, and the rest is grain boundaries with misorientation $<15^{\circ}$, which are called low angle grain boundaries (LAGBs). 


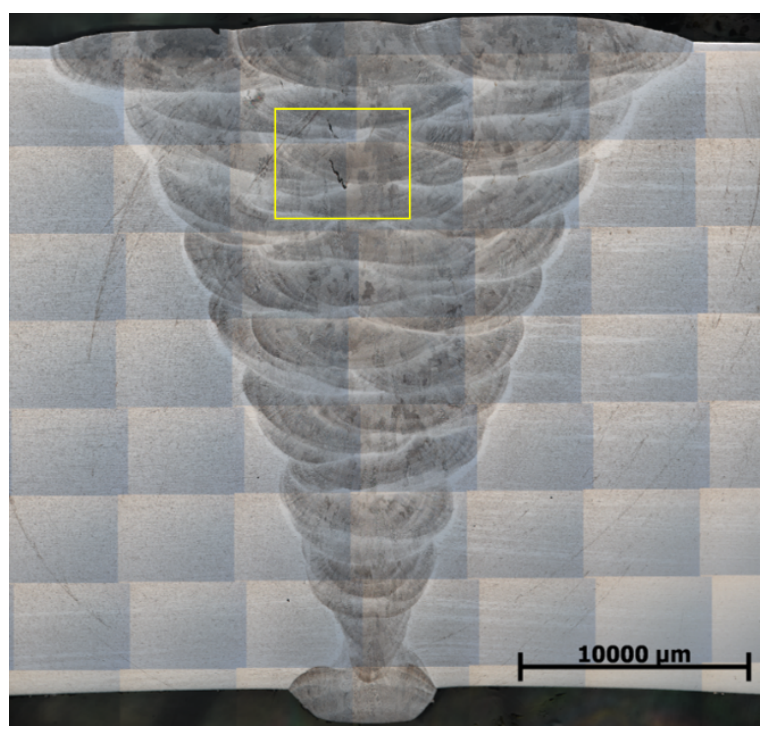

a

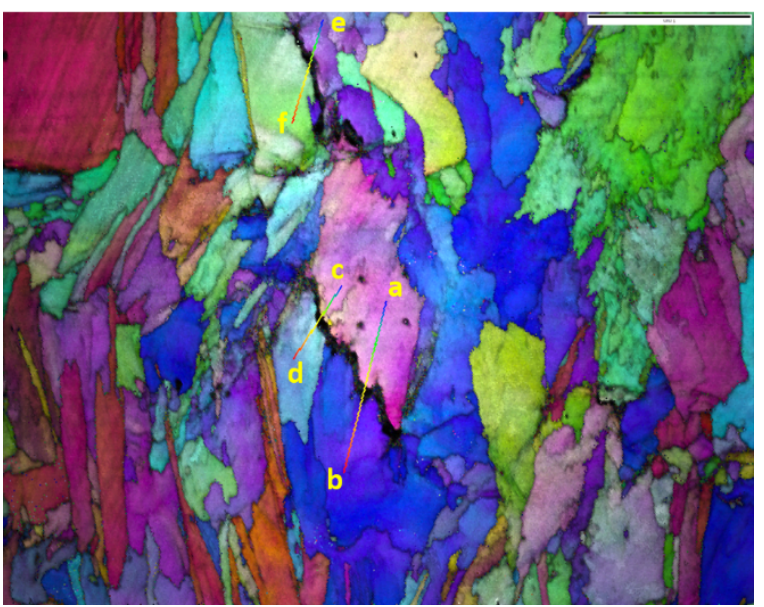

c

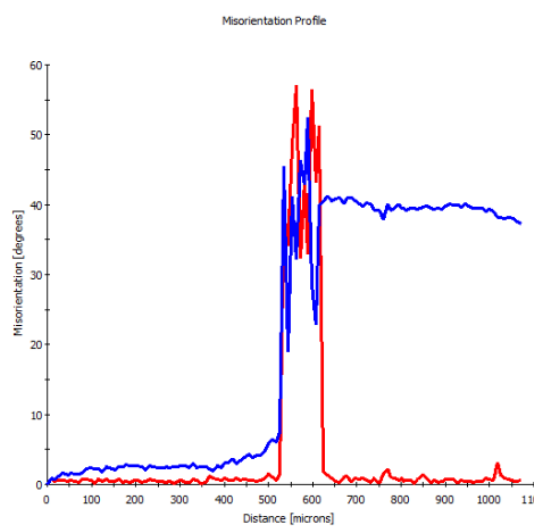

e

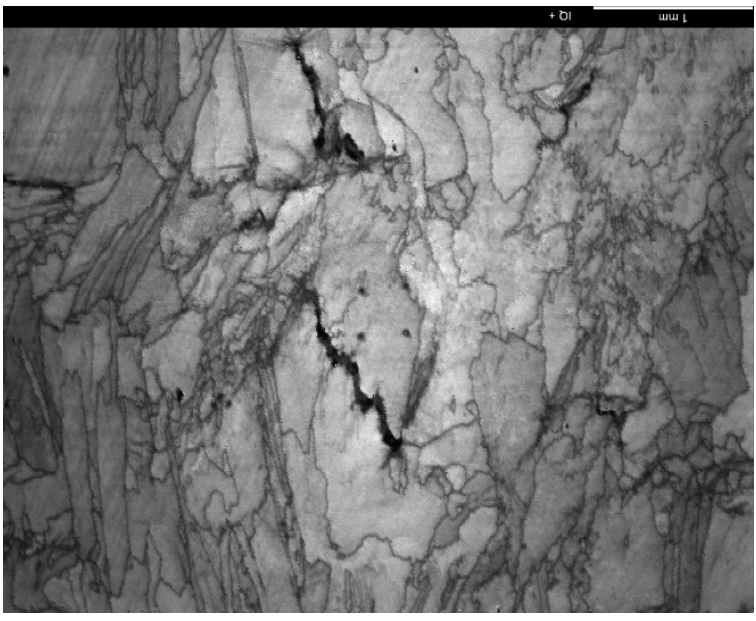

b

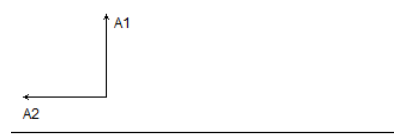

(Highlighted Points) (Total Number of Points) $=0.001$ (Highlighted Points)/(Number of Good Points) $=0.001$ (Highilighted Points)(Number of Partition Points) $=0.001$

Gray Scale Map Type:Image Quality

Cor

Color Coded Map Typ:
Plane Normal (Pole)

Austenite

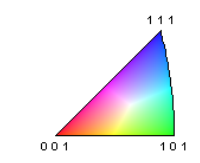

Boundaries: <none>

d

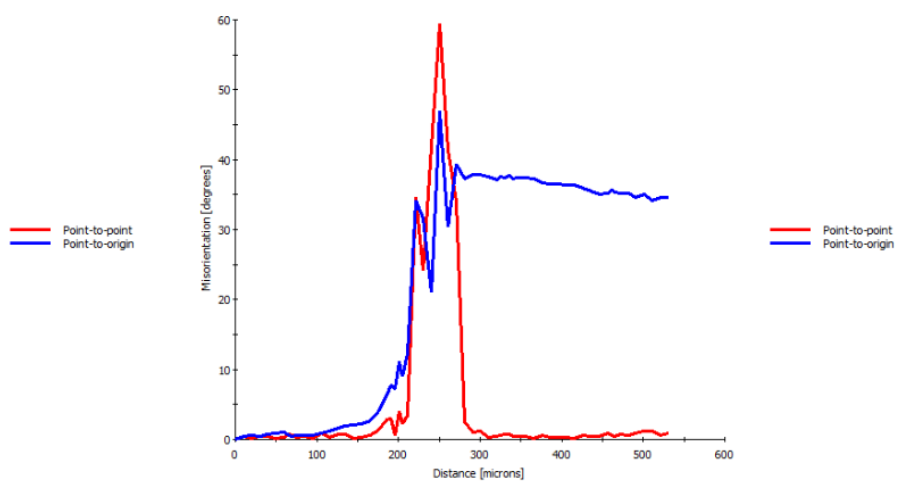




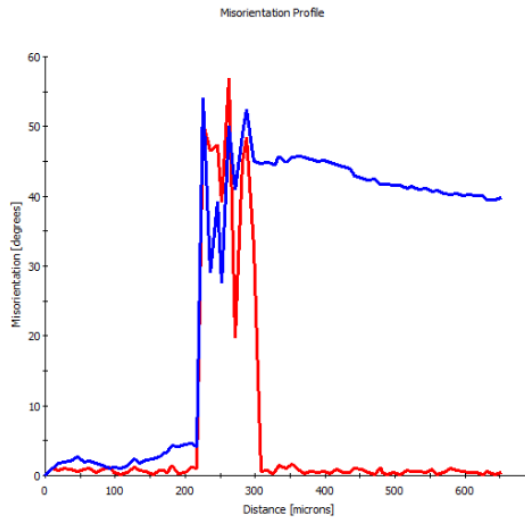

g

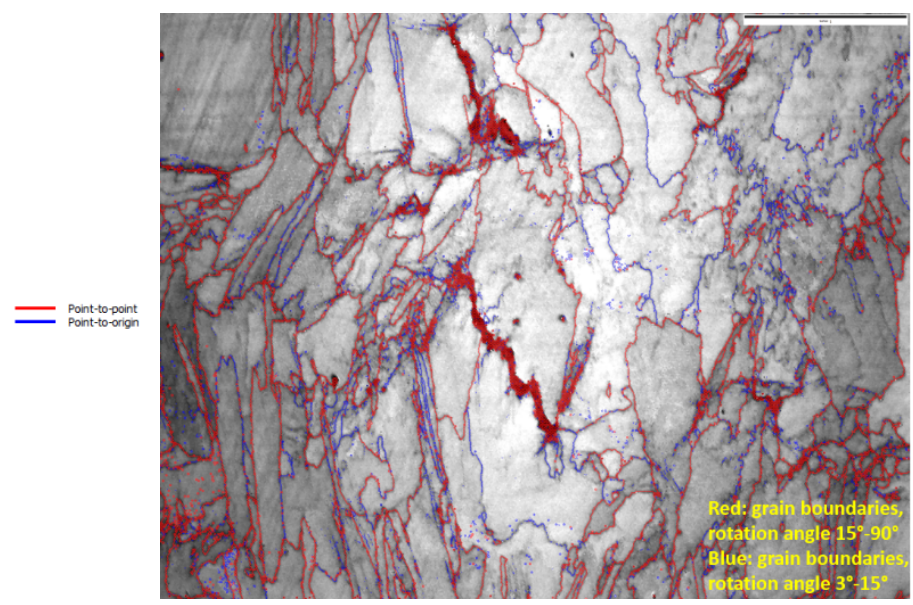

$\mathrm{h}$

Figure 16. EBSD mapping of a region with cracks. (a) the selected region with several sub-mm long cracks, (b) the grain boundaries in the selected region, (c) the overlay of the grain boundaries and inverse pole figure with three lines crossing the cracks, (d) the legend of the inverse pole figure, (e) the misorientation profile of line a$b$ in (c), (f) the misorientation profile of line $c-d$ in (c), (g) the misorientation profile of line e-f in (c), (h) the low and high angle grain boundaries in the region

\subsection{W5 WELD}

As described in Section 3.1, Weld W5 passed the ASME Sec IX weld qualification test. However, microstructure characterization revealed that sub-mm cracks in the range of $100-300 \mu \mathrm{m}$ in length were found in the weld located in region 1, 2, 3 in the Figure 17a. Figure 17b, $\mathrm{c}$ and d respectively show the closer view of the region $1,2,3$. The cracks are along the solidification grain boundaries and probably localized solidification cracking occurred during welding. It should be noted that the size and extent of microcracks in weld W5 were much smaller than weld W4.

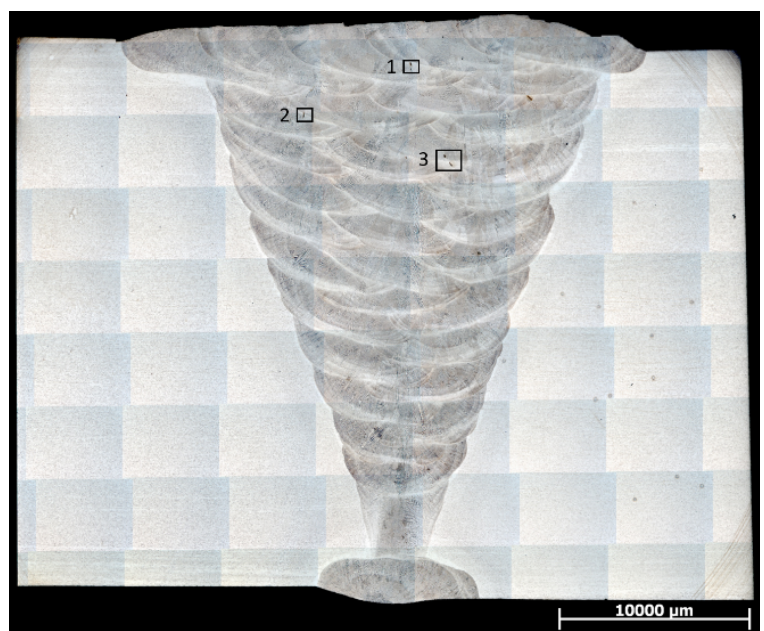

$\mathrm{a}$

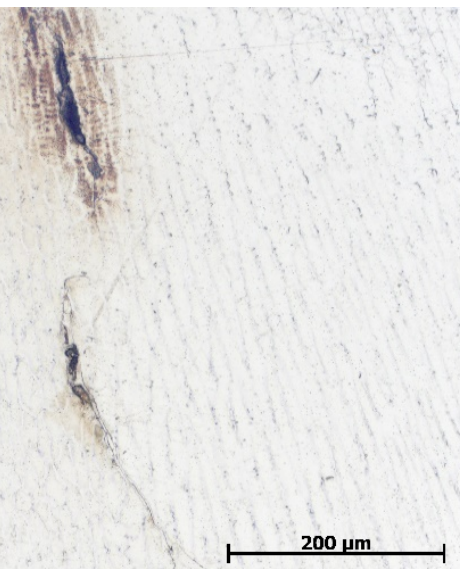

b 


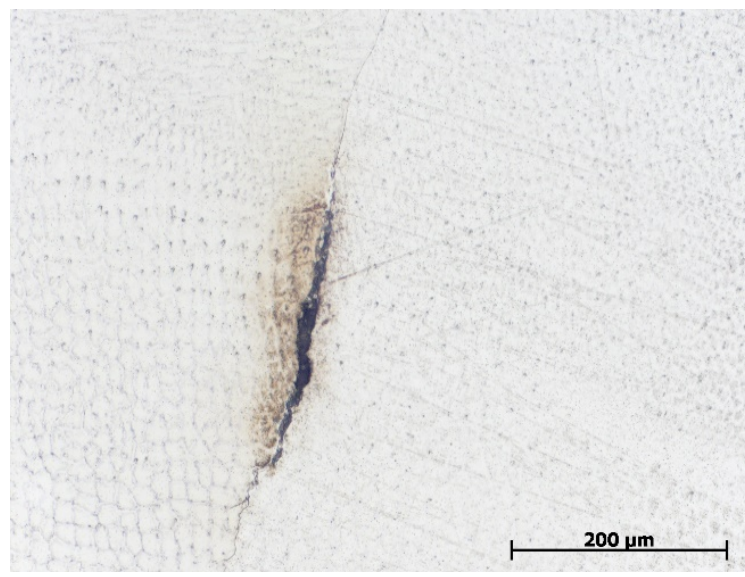

C

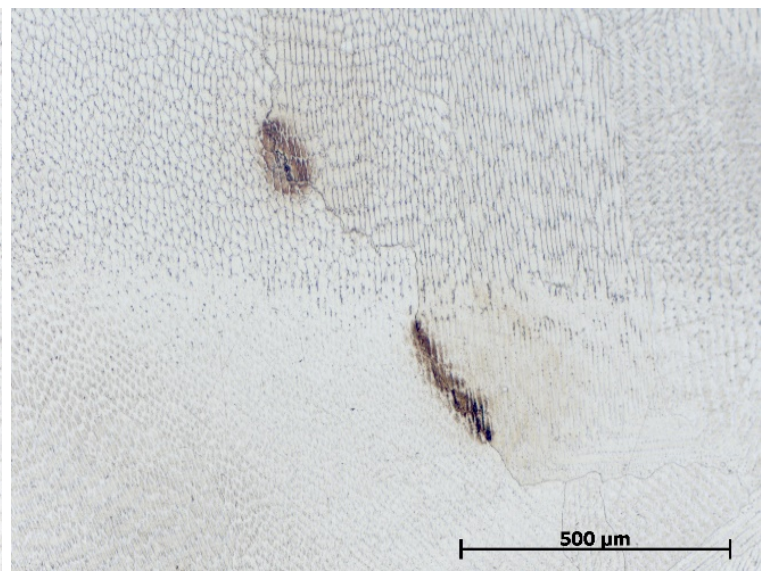

d

Figure 17. (a) the overview of 709 weld-5, (b) the cracks in region 1 of Fig. 4a, (c) the crack in region 2 of Fig. $4 a$, and (d) the cracks in region 3 of Fig. $4 a$. 


\section{PRELIMINARY CREEP TESTING OF ALLOY 709 WELDS}

High temperature creep testing was initiated on welds W2 and W5. Both of the two welds passed room temperature qualification tests. 5 cross-weld creep specimens were machined from each weld and Figure 5 shows the creep specimen layout for weld W5. Creep test conditions were selected to evaluate their creep resistance relative to the creep performance of the corresponding ESR base metal (ESR 587763RBB) from which the welds were made. Table 6 lists the creep test conditions and status for both welds.

Table 6. Preliminary creep testing of Alloy 709 welds fabricated on ESR plates SA at $1100^{\circ} \mathrm{C}$

\begin{tabular}{|c|c|c|c|c|c|c|c|}
\hline $\begin{array}{c}\text { Alloy } \\
709 \\
\text { welds } \\
\end{array}$ & P level & $\begin{array}{l}\text { Room } \\
\text { temperature } \\
\text { qualification }\end{array}$ & $\begin{array}{c}\text { Test } \\
\text { number }\end{array}$ & $\begin{array}{l}\text { Stress, } \\
\text { MPa }\end{array}$ & $\begin{array}{c}\text { Temp, } \\
{ }^{\circ} \mathrm{C}\end{array}$ & Status & $\begin{array}{l}\text { Rupture } \\
\text { time, hr }\end{array}$ \\
\hline \multirow{5}{*}{ W2 } & \multirow{3}{*}{$\begin{array}{l}\text { Weld wire: } \\
\mathrm{P}<20 \text { wppm; }\end{array}$} & \multirow{5}{*}{$\begin{array}{l}\text { Passed Section } \\
\text { IX requirements }\end{array}$} & 34276 & 330 & 600 & ruptured & 602.7 \\
\hline & & & 34325 & 330 & 600 & ruptured & 378 \\
\hline & & & 34455 & 330 & 600 & ruptured & 353 \\
\hline & \multirow{2}{*}{$\begin{array}{l}\text { Base meatal } \\
\text { P: } 140 \mathrm{wppm}\end{array}$} & & 34456 & 27 & 925 & ruptured & 342 \\
\hline & & & 34458 & 80 & 775 & ruptured & 2300 \\
\hline \multirow{5}{*}{ W5 } & \multirow{5}{*}{$\begin{array}{l}\text { Weld wire P: } \\
\text { 140wppm; } \\
\text { Base meatal } \\
\text { P: 140wppm }\end{array}$} & \multirow{5}{*}{$\begin{array}{l}\text { Passed Section } \\
\text { IX requirements }\end{array}$} & 38440 & 330 & 600 & ruptured & 6.5 \\
\hline & & & 38439 & 175 & 650 & running & -- \\
\hline & & & 38468 & 175 & 625 & running & -- \\
\hline & & & 38467 & 150 & 650 & running & -- \\
\hline & & & 38469 & 80 & 775 & ruptured & 2464.5 \\
\hline
\end{tabular}




\subsection{W2 WELD}

All the 5 specimens tested for W2, fabricated with low P weld wire, were tested to final rupture. The rupture time was compared with the base metal in
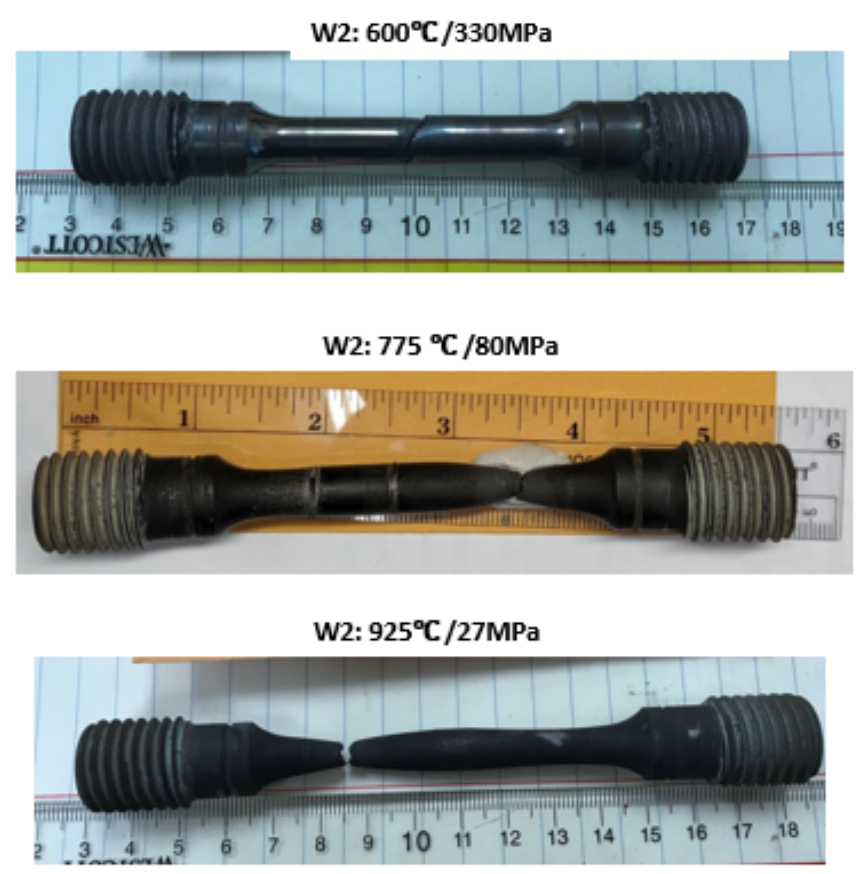

Figure 19. Photographs of the failed W2 weld specimens

W5 Weld. The three duplicate creep tests at $600^{\circ} \mathrm{C}$ and $330 \mathrm{MPa}$ showed significant reduction of creep life, whereas the tests at both $775^{\circ} \mathrm{C}$ and $80 \mathrm{MPa}$, and $925^{\circ} \mathrm{C}$ and $27 \mathrm{MPa}$ showed no reduction in creep life. It is noted that the high stress of $330 \mathrm{MPa}$ at $600^{\circ} \mathrm{C}$ passed the yield strength of the material, and about

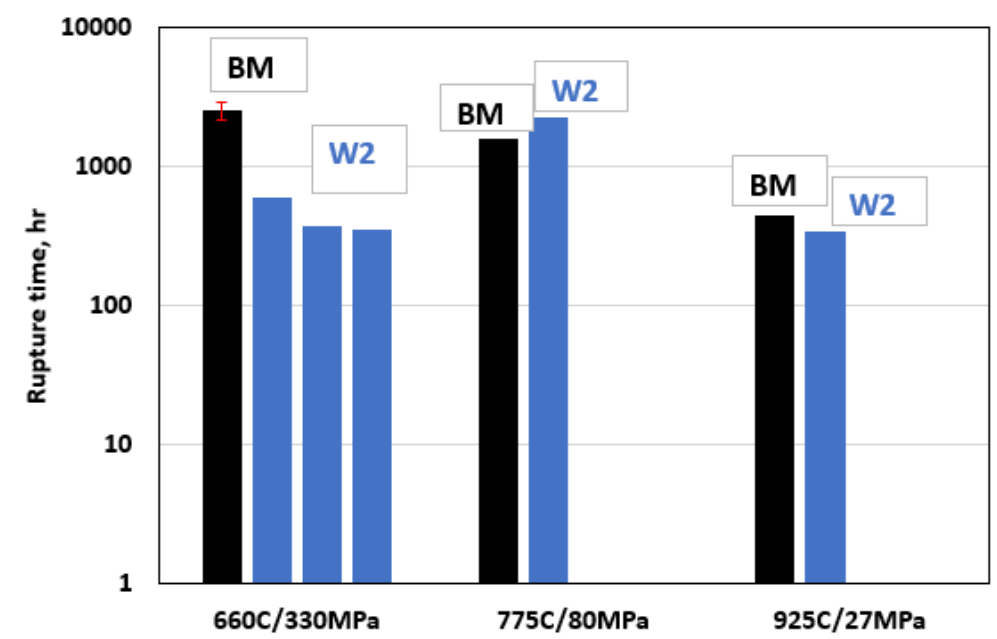

Figure 18. Comparison of the creep test results on W2 weld with Alloy 709 base metal 
Photographs of the ruptured creep specimens were shown in Error! Reference source not found. for W 2. Note that creep specimens tested at $600^{\circ} \mathrm{C} / 330 \mathrm{MPa}$ failed inside the welds, whereas all other conditions showed failure locations in the base metal for both welds.
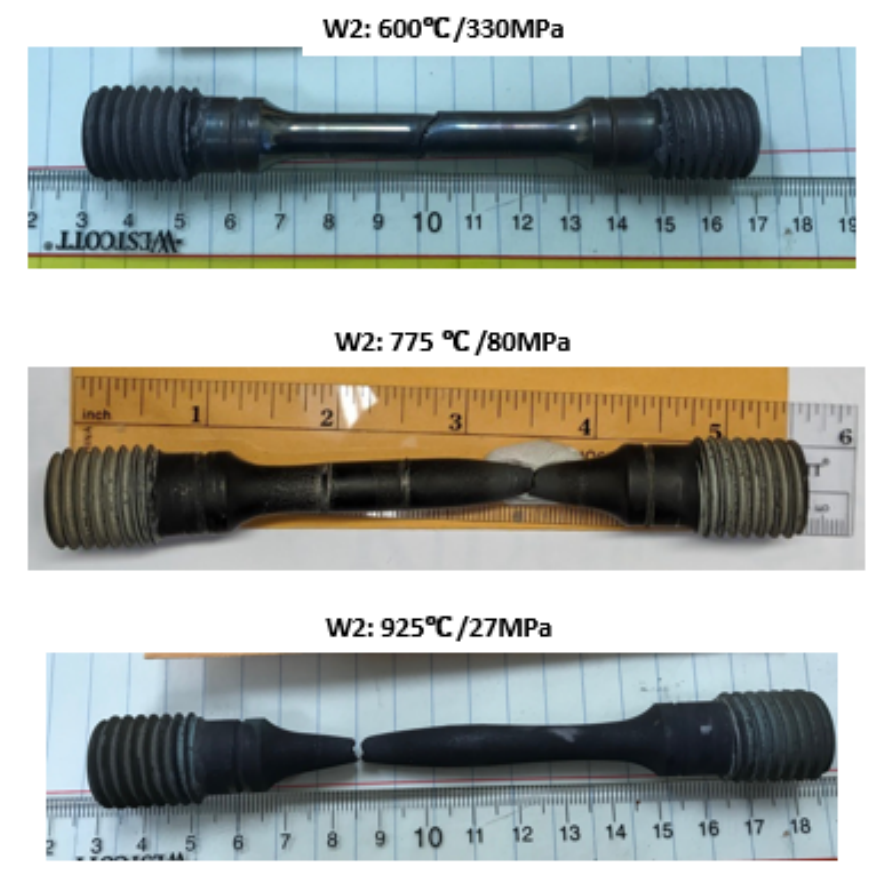

Figure 19. Photographs of the failed W2 weld specimens

\subsection{W5 WELD}

W5 weld was fabricated with $140 \mathrm{ppm} P$ weld wire. It exhibited very weak creep resistance at $600^{\circ} \mathrm{C}$ and $330 \mathrm{MPa}$. On the other hand, test at $775^{\circ} \mathrm{C}$ and $80 \mathrm{MPa}$ showed creep rupture life of $2464.5 \mathrm{hr}$, comparable to the corresponding ESR base metal creep rupture life. Both tests were compared with ESR base metal in Figure 20.

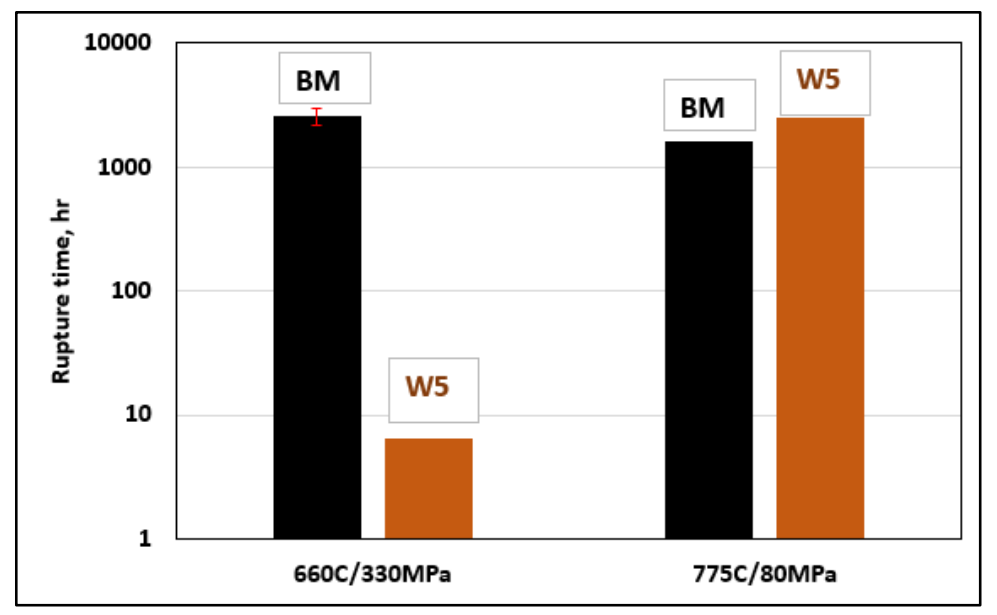

Figure 20. Comparison of the creep test results on W5 weld with Alloy 709 base metal 
Figure 21 shows the two ruptured specimens for W5, and the failure location was both inside the weld. although the test at $775^{\circ} \mathrm{C} / 80 \mathrm{MPa}$ had comparable creep life as the base metal. It is suspected that small, sub-mm long welding defects were present in W5 and dominated failure mode.
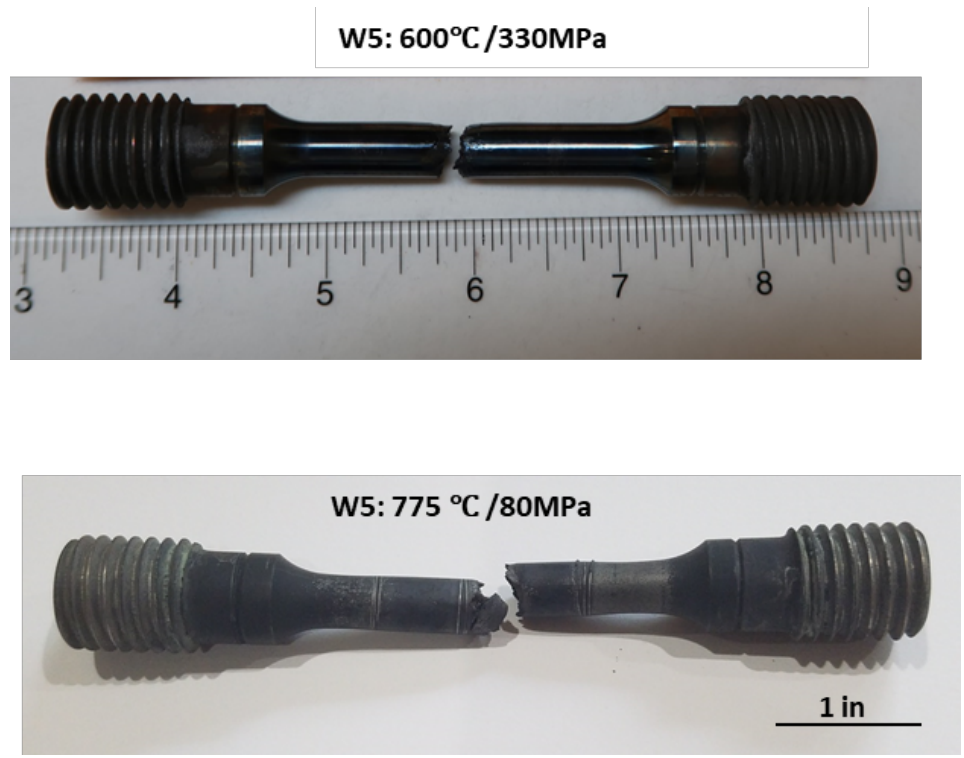

Figure 21. Photographs of the failed W5 weld specimens 


\section{SUMMARY AND FUTURE PLAN}

This report summarizes the research conducted in FY 2020 and relevant results from previous reporting periods, aimed at welding commercial heat of Alloy 709 plates of relatively high $P$ level (140wppm) in support of ASME code qualification. Welding, code qualification tests, and associated microstructure characterization were carried out in determining the effect of $P$ levels of weld wire on the weldability of the high P commercial heat of Alloy 709. Table 7 summarizes the findings of all the Alloy 709 welds fabricated on the first commercial heat Alloy 709 plates.

The study confirmed the detrimental effect of high level of $\mathrm{P}$ on weldability and the mechanical properties of Alloy 709 weld. For the commercial heat of Alloy 709 with relatively high P level (140wppm), it is possible to successfully weld it with a low phosphorous $(20 \mathrm{wppm})$ weld wire using the typical gas tungsten arc welding process and welding input levels. The preliminary weld creep showed little or no creep resistance reduction. On the other hand, micro cracks or fissures are observed when the phosphorous level in the weld wire increases to 140wppm. The study found that optimizing the welding process conditions such as weld wire size and welding heat input improved the weldability, although additional R\&D is necessary to completely eliminate the micro-cracks at $140 \mathrm{wppm}$ level of $\mathrm{P}$ in the weld metal. Initial weld creep test indicated that the micro-cracks that are formed due to P segregation at solidification grain boundary during welding, although acceptable to ASME Sec IX weld qualification requirement, would potentially cause premature rupture under low-temperature and high-stress creep testing conditions. On the other hand, such micro-cracks appeared to have minimal effect to weld creep test under lower stress and higher temperature conditions. This aspect would require additional study to develop sound technical basis to support the code case qualification of Alloy 709 for ASME Sec IX.

Computational simulations conducted in previous FY revealed that that phosphorous would segregate to grain boundaries as a result of non-equilibrium solidification process during welding. At high P level, grain boundary segregation would greatly increase the solidification temperature range, leading to increase in the susceptibility of weld solidification cracking of Alloy 709. EPMA micro-chemistry measurement conducted in this reporting period confirmed the computational simulation prediction of grain boundary segregation of $\mathrm{P}$. The micro-chemistry measurement also revealed the meso-scale variations of $\mathrm{P}$ within a weld pass. However, macro-scale $\mathrm{P}$ segregation/accumulation across different weld passes was not apparent based on the micro-chemistry measurement.

The research on Alloy 709 weldability in this program so far supports the strategy for successfully welding Alloy 709 having wide range of chemistries without weld solidification cracking. The strategy includes the use of low phosphorous level weld wire to weld Alloy 709 having relatively high P. It also includes segregation control and/or stress control welding techniques for P level higher than the above threshold situations. To this end, future FY R\&D plan includes to quantitatively determine the threshold or the upper limit of P level that will not cause solidification cracking through systematic weldability study, for commonly used arc welding processes such as GTAW, shielded metal arc welding (SMAW), electron-beam welding. 
Table 7. Summary of the welds fabricated with V-groove geometry on the $1^{\text {st }}$ commercial heat Alloy 709

\begin{tabular}{|c|c|c|c|c|c|c|}
\hline \multirow{2}{*}{$\begin{array}{l}\text { Weld } \\
\text { ID }\end{array}$} & \multirow{2}{*}{ Weld Wire } & \multirow{2}{*}{ Base Metal } & \multicolumn{3}{|c|}{ ASME Sec. IX Weld Qualification } & \multirow[t]{2}{*}{ Creep } \\
\hline & & & $X-R a y$ & Side Bend & RT Tensile & \\
\hline W1 & \multirow{2}{*}{$\begin{array}{l}\text { Alloy } 709 \text { Low P (<20wppm), 0.064” dia } \\
\text { (Heat No 011367-08) }\end{array}$} & $\begin{array}{l}\text { AOD: 140wppm P,0.8125” thick } \\
\text { (Heat No 58776-4B), }\end{array}$ & Passed & Passed & Passed & None \\
\hline W2 & & $\begin{array}{l}\text { ESR 140wppm P, 1.125" thick } \\
\text { (Heat No 58776-3RBB) }\end{array}$ & Passed & Passed & Passed & 5 tests \\
\hline W3 & \multirow{2}{*}{$\begin{array}{l}\text { Alloy } 709 \text { High P (140wppm), 0.064” dia. } \\
\text { (Heat No 58776-4A1) }\end{array}$} & \multirow{3}{*}{$\begin{array}{l}\text { ESR 140wppm P, 1.125” thick } \\
\text { (Heat No 58776-3RBB) }\end{array}$} & Failed & $\mathrm{N} / \mathrm{A}$ & N/A & none \\
\hline W4 & & & Passed & Passed & Failed & none \\
\hline W5 & $\begin{array}{l}\text { Alloy } 709 \text { High P (140wppm), 0.045" dia. } \\
\text { (Heat No 58776-4A1) }\end{array}$ & & Passed & Passed & Passed & 5 tests \\
\hline W6 & $\begin{array}{l}\text { Alloy } 709 \text { High P (140wppm), 0.035" dia. } \\
\text { (Heat No 58776-4A1) }\end{array}$ & $\begin{array}{l}\text { ESR 140wppm P, 1.125" thick } \\
\text { (Heat No 58776-3RBC-HT) }\end{array}$ & Passed & Passed & Planned & Planned \\
\hline
\end{tabular}




\section{BIBLIOGRAPHY}

ASME. 2019. Qualification Standard for Welding, Brazing, and Fusing Procedures; Welders; Brazers; and Welding, Brazing, and Fusing Operators. ASME Boiler and Pressure Code.

ASTM International. 2015. Standard Specification for Seamless Ferritic and Austenitic Alloy-Steel Boiler, Superheater, and Heat-Exchanger Tubes. ASTM International.

Busby, Jeremy T, S Byun, R Klueh, P Maziasz, John M Vitek, K Natesan, Meimei Li, et al. 2008. Candidate Developmental Alloys for Improved Structural Materials for Fast Reactors. Oak Ridge National Laboratory, ORNL/GNEP/LTR-2008-023.

Feng, Zhili, John M Vitek, Tingkun Liu, and Yanli Wang. 2018. Evaluation of the Effect of Alloy Chemistry on the Susceptibility of Weld Solidification Cracking of Alloy 709 Weldment and Development of Mitigation Strategy. Oak Ridge National Laboratory, ORNL/TM-2018/965.

Natesan, K Natesan, X Zhang, T-L Sham, and Hong Wang. 2017. Report on the completion of the procurement of the first heat of Alloy 709. Argonne National Laboratory, ANL-ART-89.

NIPPON STEEL \& SUMITOMO STEEL. 2013. "NF709 Material Data Sheet." http://www.tubular.nssmc.com/product-services/specialty-tube/product/nf709.

Sham, T-L, and K Natesan. 2017. "Code Qualification Plan for an Advanced Austenitic Stainless Steel, Alloy 709, for Sodium Fast Reactor Structural Applications." International Conference on Fast Reactors and Related Fuel Cycles. Yekaterinburg, Russian Federation. IAEA-CN-245-74.

Yamamoto, Y. 2014. "Unpublished data." Oak Ridge National Laboratory. 